\title{
IDENTIFICATION OF KEY-TRENDS AND EVALUATION OF CONTEMPORARY RESEARCH REGARDING URBAN ECOSYSTEM SERVICES: A PATH TOWARDS SOCIO- ECOLOGICAL SUSTAINABILITY OF URBAN AREAS
}

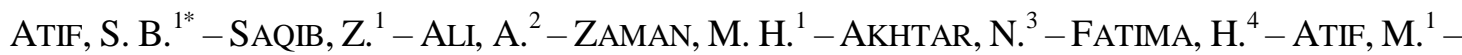 \\ FAROOQI, S. M. ${ }^{5}$ \\ ${ }^{I}$ GIS and Eco-Informatics Laboratory, Department of Environmental Science \\ International Islamic University \\ Sector H-10, Islamabad 44000, Pakistan \\ ${ }^{2}$ Pakistan Space and Upper Atmosphere Research Commission (SUPARCO) \\ Off University Road, Karachi, Pakistan \\ ${ }^{3}$ Department of Environmental Science, International Islamic University (Female Campus) \\ Sector H-10, Islamabad 44000, Pakistan \\ ${ }^{4}$ Department of Environmental Sciences, Allama Iqbal Open University \\ Sector H-8, Islamabad 44000, Pakistan \\ ${ }^{5}$ Department of Geography, Government College, Asghar Mall, Rawalpindi \\ Pakistan \\ *Corresponding author \\ e-mail: syedatifbokhari@gmail.com \\ (Received 22 ${ }^{\text {nd }}$ Mar 2018; accepted 25 $5^{\text {th }}$ May 2018)
}

\begin{abstract}
The challenges accompanying socio-ecological and demographic transformations in the urban areas necessitate for coordinated efforts to ensure urban ecological resilience. Trans-disciplinary analytical construct of urban ecosystem services (UES) empowers the policy makers and urban planners to synchronize the orientations of human impacts and resilience of ecological resources in urban areas. The current study provides a systematic overview about the research orientations, approaches and techniques used in the recent studies regarding UES. The study examined: what types of evaluation methods were adopted in the recent UES research? What is their spatial and temporal pattern? What types of UES were focused and environmental components relied upon for the assessment? To address these questions, 116 relevant publications were scrutinized by using a set of assessment criteria. The findings indicated a lesser focus in research towards UES in developing countries as compared to the volume and increasing share of their urban population. The study also establishes that an overwhelming proportion of the UES research was carried out in the industrialized countries of the northern hemisphere but rather skewed towards studying regulatory ecosystem services. The recommendations for improving the relevancy of contemporary research for stakeholders were made.
\end{abstract}

Keywords: urban ecosystem services, ecosystem disservices, urbanization, socio-ecological systems, urban environment, resilience, urban ecology

\section{Introduction}

The contributions of natural resources to social and economic systems are referred to as ecosystem services (ES) defined as the benefits humans draw from the functioning and processes of ecological systems (Costanza et al., 1997; Daily et al., 1997; De Groot et al., 2002). It is acknowledged that the life on the planet Earth is a product of and 
dependent upon the constant support and productivity of ecosystems and services arising thereby (De Groot et al., 2002). These benefits from the ecological resources are classified into four major groups or categories i.e. regulatory, cultural, provisioning and supporting services (De Groot et al., 2002; Millennium Ecosystem Assessment, 2005a).

The birth of new urban settlements and/or the increase in the size of existing urban centers at the cost of non-urban land usages pose(s) new social and environmental challenges (Haase et al., 2014b). The increase in the proportion of global urban population (Heilig, 2012; Haase et al., 2014b), transformations in the urban based economic activities and concomitant life style changes in the urban centers have their visible impacts on the natural environment. The conjectured estimations suggest that the process of urbanization will accelerate in the future (Cohen, 2004; United-Nations, 2014; Graça et al., 2017). The promising technological advancements are sometimes misconstrued as a replacement for the natural ecosystems of urban areas. These advancements can supplement the contributions of natural ecological systems in an urban area but are incapable of substituting their role (Honey-Rosés et al., 2014).

The term "ecosystem services", initially appeared in Ehrlich and Ehrlich's work in 1981 (Liu et al., 2010; Chaudhary et al., 2015) while highlighting the contribution of ecological systems for human life. Now the term ES is frequently used for assessing the material contribution of natural resources in human wellbeing. The concept provides a common vocabulary for evaluating tripartite linkages between ecological, social and economic systems to ensure their integrated management. The concept of ES has proven useful, firstly, to synthesize the efforts for linking human and ecological systems for coherence and sustainability (Costanza and Daly, 1987; Daily et al., 2009). Secondly, scientists and policy makers rely on the concept while evaluating economic and political tradeoffs between landscape development and conservation alternatives (De Groot et al., 2010; Mcshane et al., 2011; Bürgi et al., 2015).

The analytical construct of Urban Ecosystem Services (UES) is relied upon for the assessment, management and conservation of the urban ecological resources and their correlation with human life. The paradigm of UES seems to be a more pragmatic strategy to ensure that the impacts of urbanization, climate change and socio-ecological transformations on the urban environment are addressed.

The first studies on UES date back to the mid-1990s (Cairns Jr and Palmer, 1995) but the interest in this sphere had spread worldwide by the end of the last century (Bolund and Hunhammar, 1999). The researchers such as Alavipanah et al. (2017), supported the previous findings of (Gómez-Baggethun et al., 2010; Kronenberg and Hubacek, 2013; Haase et al., 2014b) that less than $10 \%$ of ES research in scientific publications was investigated in urban areas and also depicted a decline in the publication concerning UES after 2015.

It transpires from scholarly efforts that the demands for UES are mounting but paradoxically the efforts are less focused to address the challenges associated with the urban environment (Millennium Ecosystem Assessment, 2005b; Haase et al., 2014b). The situation demands a systematic review of UES studies based upon an innovative framework for postulating pragmatic measures to improve the orientations, trends and techniques in research regarding UES.

Keeping in view these expectations, the current study was designed to decipher various dimensions of UES research in recent years. In this connection, the present review was carried out on the basis of selected research publications to analyze: 1) The current spatial-temporal trends in UES research 2) To weigh research orientations, 
approaches, and techniques adopted in the recent studies 3) to evaluate the components of urban environment used for assessments in the reviewed publications. The outcomes of the current study will provide insights and innovative options for integrating efforts to ensure the sustainable provision of UES.

\section{Material and method}

The current review is a meta-analysis and is based upon the bibliographic information obtained from ISI web of Knowledge (www.webofknowledge.com). The study considered the articles published in English during the period (May 2007 - May 2017) against the search term "urban ecosystem services'. The search returned a total of 127 records. Out of these, only those records were considered for further scrutiny, where, the search term UES was included in either the Title, Abstract or Keywords of a publication. On these criteria, 116 records were identified for further processing and content analysis (Appendix-1).

The content analysis of selected papers, based upon a list of assessment criteria with the predetermined choices (Table 1), was carried out to determine the current orientations of or in the UES studies, techniques and measures (monetary/nonmonetary) relied upon in the research for assessments and inferences. The information pertaining to environmental components used for evaluating UES was also extracted from the reviewed publications. A component was only included in this study, provided, it was used as a parameter for assessment to publish the article. The components with different appellations, used to assess analogous goals (such as Hedonic Pricing or Property Value; carbon absorption or storage etc.) amalgamated into a single category for brevity and analysis. In this way 10 classes were formulated to interpret trends to select component(s) for assessing UES. The quantitative findings of this analysis were cartographically displayed in Figures 1-7 for estimations and inferences.

Table 1. Selection and assessment criteria adopted for the review of selected research publicatons

\begin{tabular}{|c|c|}
\hline Criterion (question) & Possible entries \\
\hline $\begin{array}{l}\text { Which type(s) of ES were } \\
\text { analysed? }\end{array}$ & $\begin{array}{ccc}\text { i. } & \text { Regulating Services } \\
\text { ii. } & \text { Provisioning Services } \\
& \text { iii. } & \text { Cultural Services } \\
& \text { iv. } & \text { Supporting Services } \\
\text { v. } & \text { Cumulative Assessment of ES } \\
\text { vi. } & \text { Ecosystem Disservices } \\
\end{array}$ \\
\hline $\begin{array}{l}\text { From which country (city) } \\
\text { empirical data/ contextual } \\
\text { information were obtained? If } \\
\text { required for assessments. }\end{array}$ & $\begin{array}{l}\text { The name of country/city in which the site/situation of study is } \\
\text { located. }\end{array}$ \\
\hline $\begin{array}{l}\text { What is the location of } \\
\text { Principal/corresponding author of } \\
\text { the study? }\end{array}$ & The location of author \\
\hline
\end{tabular}




\begin{tabular}{|c|c|}
\hline $\begin{array}{c}\text { What kinds of evaluation } \\
\text { methods/indicators were relied } \\
\text { upon for assessments in these } \\
\text { studies? }\end{array}$ & 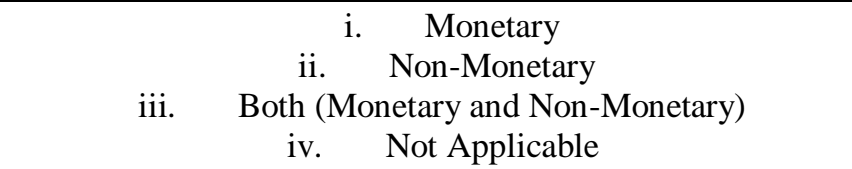 \\
\hline $\begin{array}{c}\text { What was the principal objective } \\
\text { of the study? }\end{array}$ & $\begin{array}{l}\text { The objectives of these publications were grouped into eight } \\
\text { categories on the basis of homogeneity in focus: } \\
\text { i. Planning and Management } \\
\text { ii. Assessment study } \\
\text { iii. } \quad \text { Governance and Policy } \\
\text { iv. Assessment of Method } \\
\text { v. Climate Adaption } \\
\text { vi. } \quad \text { Landuse Planning } \\
\text { vii. Urban Ecology } \\
\text { viii. Environmental Justice }\end{array}$ \\
\hline $\begin{array}{l}\text { Which specific component(S) of } \\
\text { urban environment was/ were } \\
\text { assessed? }\end{array}$ & $\begin{array}{c}\text { The name of component(s) assessed in a publication: } \\
\text { i. Aesthetics } \\
\text { ii. Biodiversity } \\
\text { iii. Carbon Sequestration/Storage } \\
\text { iv. } \quad \text { Climate Regulation } \\
\text { v. Energy } \\
\text { vi. Food Fuel } \\
\text { vii. } \quad \text { Hedonic Pricing } \\
\text { viii. Others } \\
\text { ix. } \quad \text { Socioecological } \\
\text { x. } \quad \text { Water Management }\end{array}$ \\
\hline $\begin{array}{l}\text { What type of enquiry technique } \\
\text { was used in the study? }\end{array}$ & $\begin{array}{cc}\text { i. } & \text { Assessment (technique)study } \\
\text { ii. } & \text { Experimental (technique)study } \\
\text { iii. } & \text { Exploratory (technique) method } \\
\text { iv. } & \text { Conceptual Framework }\end{array}$ \\
\hline $\begin{array}{l}\text { What was the principal } \\
\text { consideration of the study? }\end{array}$ & $\begin{array}{l}\text { The content analysis revealed that reviewed studies were } \\
\text { inherently designed to address the impacts of the following } \\
\text { challenge (s): } \\
\text { i. urbanization, } \\
\text { ii. climate change } \\
\text { iii. Loss of urban biodiversity }\end{array}$ \\
\hline
\end{tabular}

\section{Results}

\section{Spatio-temporal trends}

The temporal analysis of these publications in Figure 1 reflected an upward trend to use the term UES in title, abstract or keywords in the initial years of the selected timeframe. However, a decline in tendency to use the term UES in publications was noticed in the last two years of the selected period.

The Figure 2 illustrates that a leading share of UES research was carried out in European (62.71\%) and North American (23.73\%) contextual surroundings. The contributions in UES research from other continents were found disproportionately less as compared to the proportion of people residing in the urban areas of these continents (Figure 2).

The spatial analysis of these selected publications revealed (Figure 3) that a predominant proportion of UES research (99\%) was carried out in the contextual settings of the northern hemisphere while the share from the southern hemisphere was found to be the less than (1\%).The significant intra-continental inequalities in the publications regarding UES were also observed (Figure 3). In this connection, the 
contributions from Germany (20) are significantly higher than those from other European countries; China (4) is at the forefront from Asia while the USA (24) is the leading country in North America. The city of Berlin (Germany) was most frequently assessed in (9) studies from different perspectives of UES and followed by New York (USA) in (7) and Stockholm (Sweden) in (6) studies (Appendix-2).

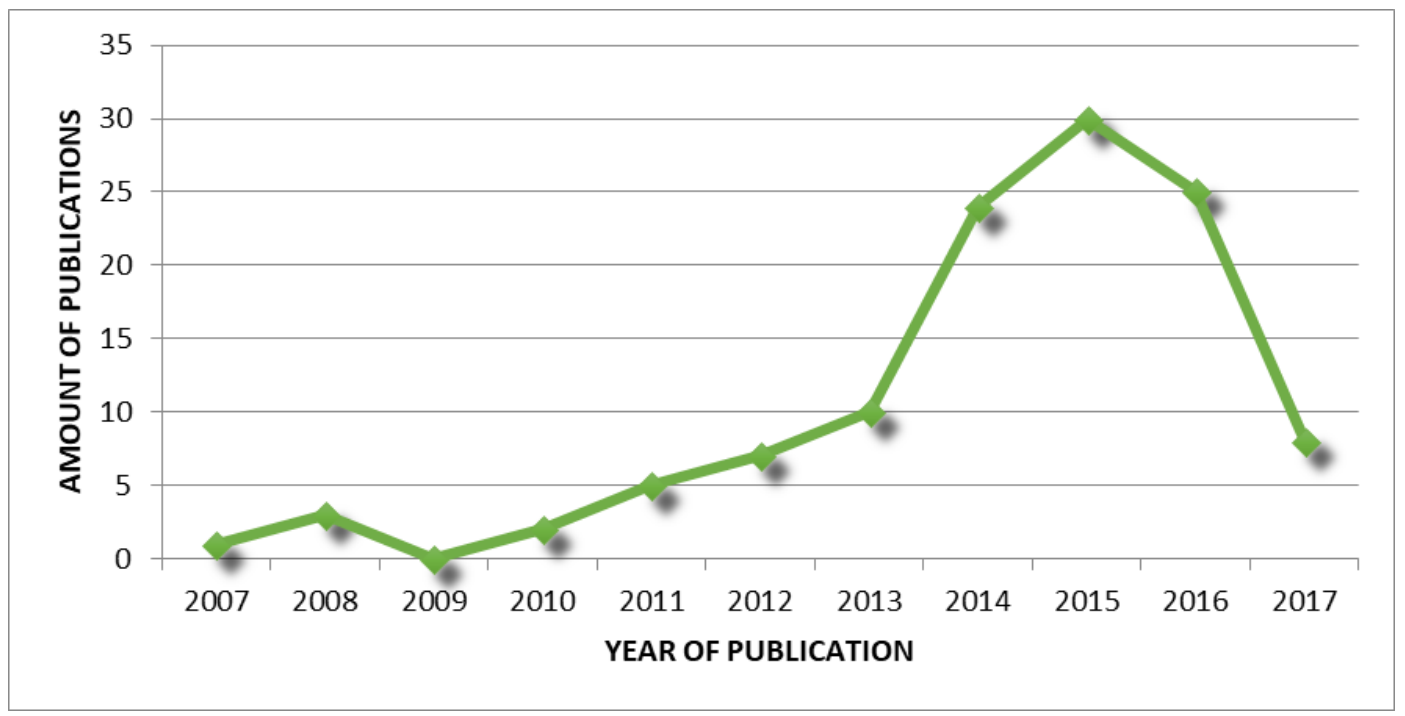

Figure 1. The year wise distribution of publications which used the term UES during the period (2007-2017)

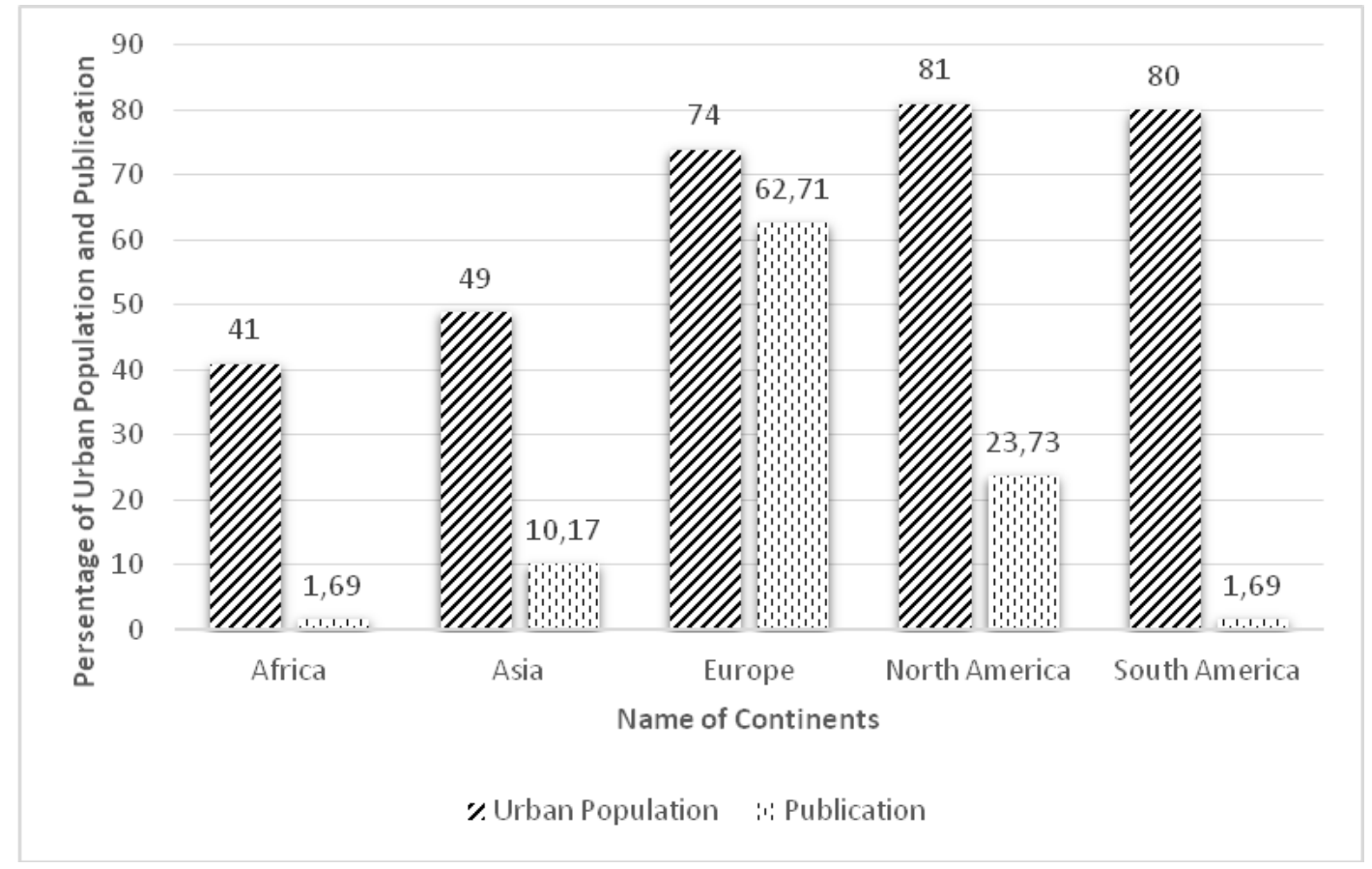

Figure 2. Graph comparing the contribution in urban ecosystem research and the proportion of urban population of a continent (Urban population data Source: https://www.statista.com) 


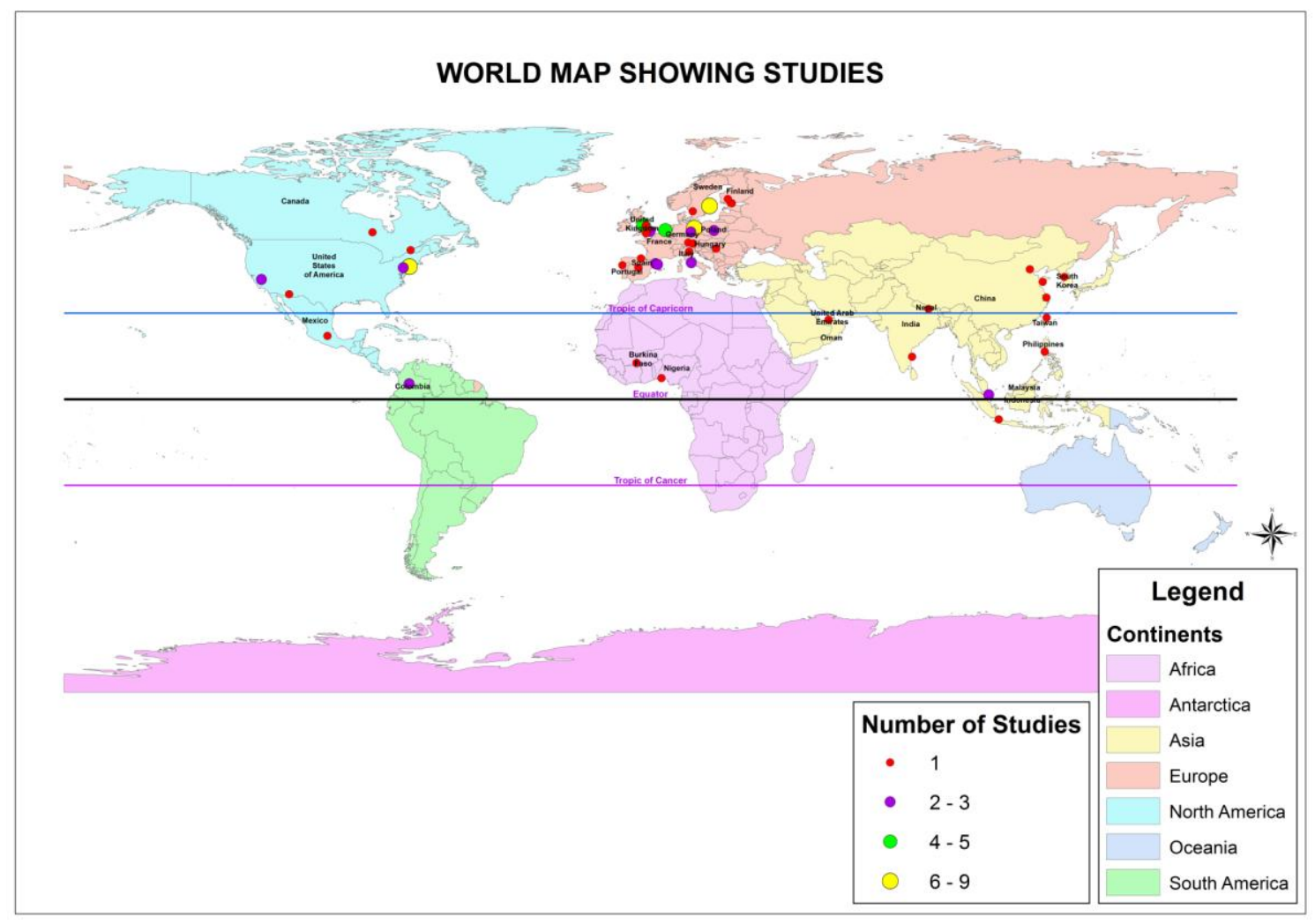

Figure 3. World map showing locations and the numbers of UES studies

The use of term UES in the title, abstract or keyword of a publication provides a measure to assess how much importance is given in research on highlighting the contributions of green infrastructure in urban social life. The Figure 4 explicitly describes the frequency with which the term UES was used in the title, abstract and keywords of reviewed publications. The term urban ecosystem services was most frequently used in the abstracts (70), followed by keywords (56) and titles of (41) the reviewed publications.

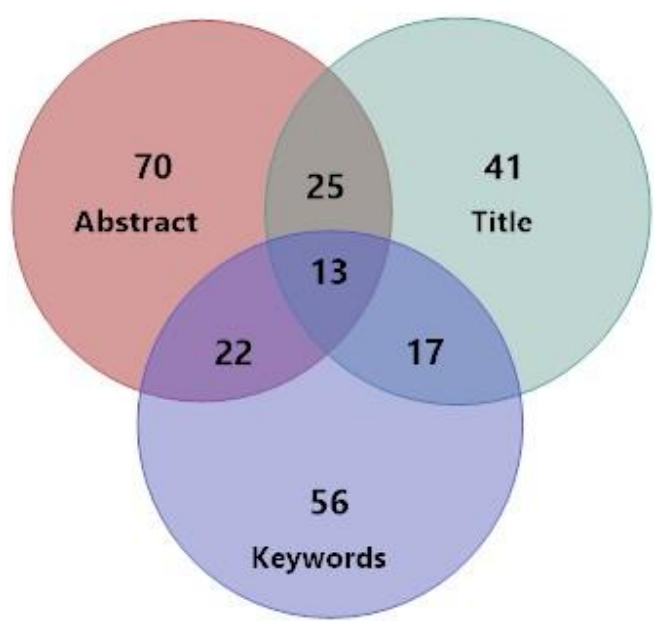

Figure 4. Showing the use of the term UES in abstract, title and keywords 


\section{Types of UES and research trends}

The intertwined and overlapping nature of contributions from UES makes it more intricate to catalogue a study into a specific category of services. As a pragmatic measure to overcome the problem, a specific study was simultaneously catalogued into different categories of ecosystem services provided these services were tested/evaluated in the publication. In the majority of publications, the focus of research was observed on the cumulative assessment of UES. It was followed by the deliberations on Regulatory services, cultural services and provisioning services. While the supporting services were assessed the least. However, urban ecosystem disservices (UESD) were also focused in (13) publications (Figure 5).

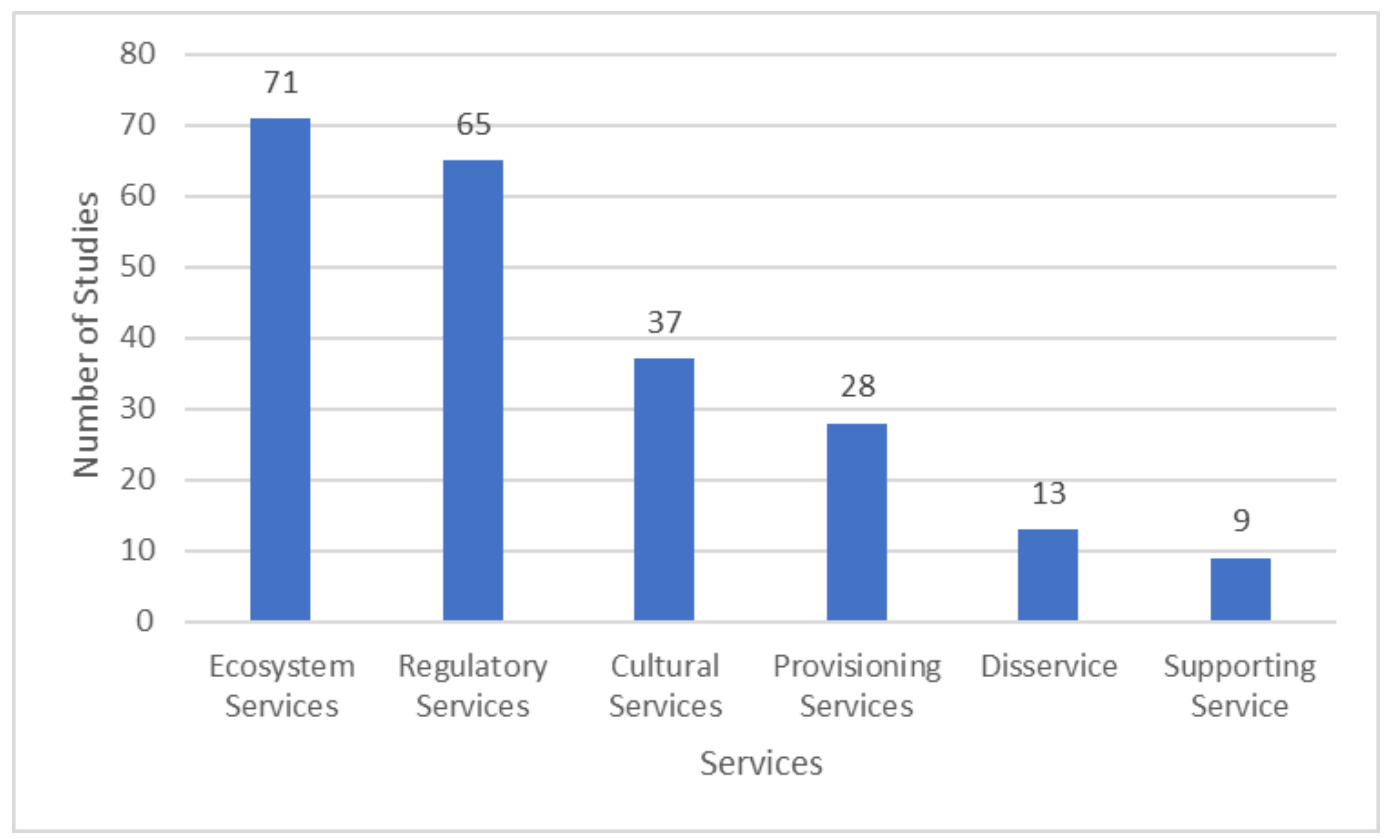

Figure 5. Graph showing number of studies designed to focus the types of ecosystem services and disservices

\section{Study paradigms and UES}

The impacts of urbanization, ecological degradations in urban areas and threats from global climatic changes are the potential stressors for UES. The content analysis of selected publications was carried out for assessing how much emphasis is being given to these stressors in UES studies. The findings in Figure 6 revealed an intersecting nature of research inclinations. It also enumerates the number of studies designed to scrutinize the role of these stressors on the resilience of UES.

\section{The trends in UES assessments}

The findings of content analysis have been condensed in Figure 7 to illustrate the numbers and proportion of studies focusing on a particular type of ES: nature of methods/indicators opted for evaluation, types of techniques relied upon for investigations, research or study objective(s) in contemporary research and selection of environmental component(S) for measurements (Appendix-3). These findings are indispensable for interpreting contemporary trends in UES studies. 


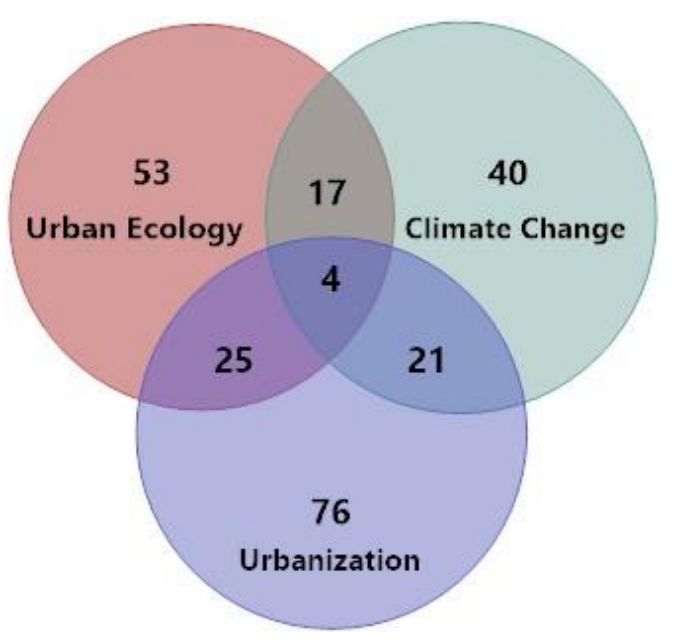

Figure 6. Showing the focus of recent UES research

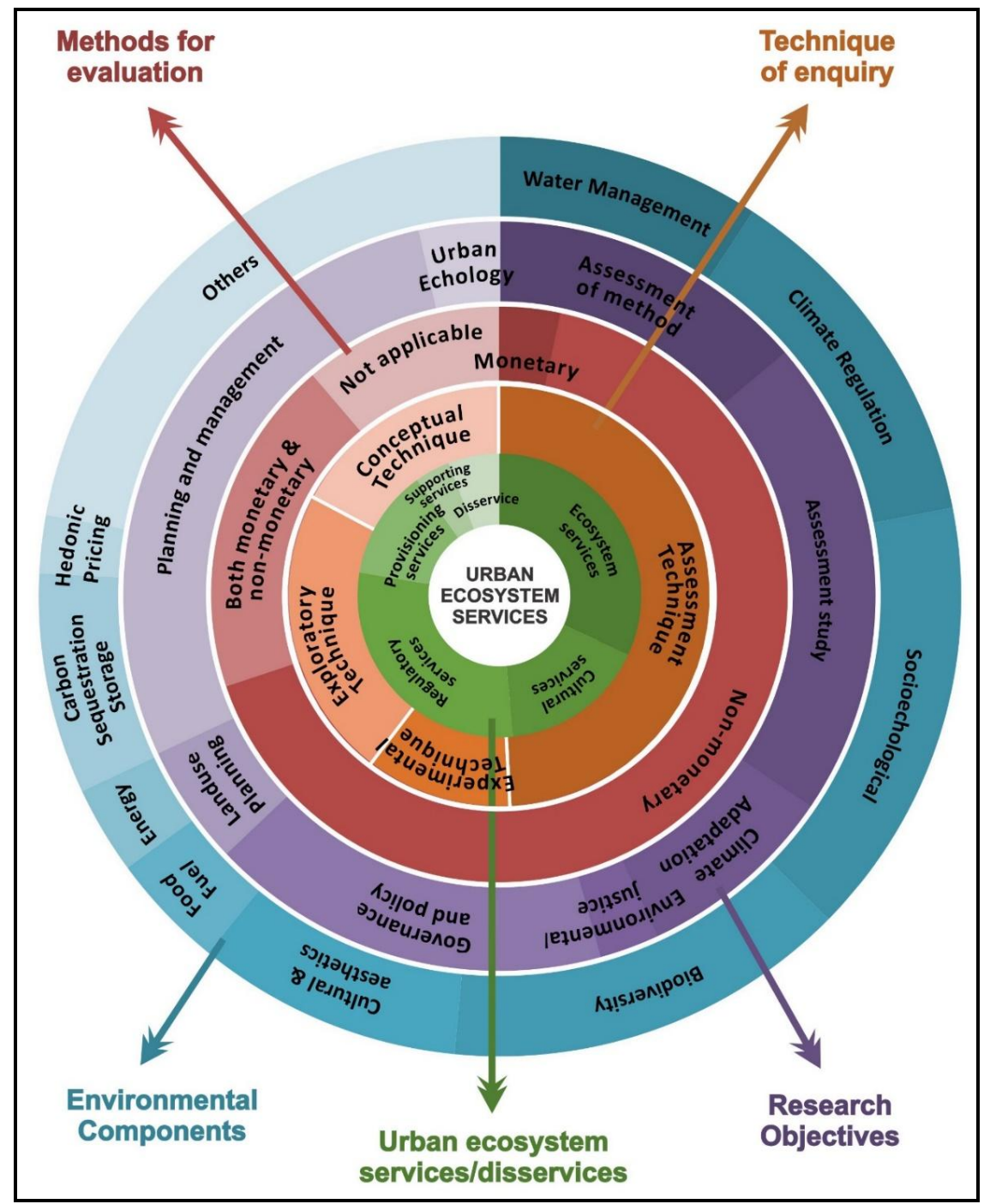

Figure 7. The Multi-pie diagram showing types and proportion of environmental components, research objectives, evaluating methods, techniques for enquiry and types of UES relied upon in recent research 


\section{Discussion}

\section{Trends and techniques used in UES evaluation}

The contingent valuation techniques proposed by Ciriacy-Wantrup in 1947, laid the foundations of Ecosystem Valuation (ESV) in modern times (Ciriacy-Wantrup, 1947; Spash, 2011; Mitchell and Carson, 2013) and a subsequent fervor for environmentalism in the 1960s, providing the much needed impetus to ESV (Liu et al., 2010; Salzman, 2011).

The findings in Figure 5 indicated that Regulatory services (RS) are more in focus of the contemporary UES research compared to the other three types of ES or ESDS. It is followed by the focus of researchers on studying cultural services (CS) and Provisioning services (PS). In this connection, supporting services (SS) were observed as a lesser priority area of investigation. These dissimilarities in focus towards different types of UES are due to the nature of urban economic activities and socio-cultural life style of urban areas. Besides this, a recent surge in reported incidents of "urban heat island effect" and exacerbating climatic and environmental settings of urban areas are other plausible explanations for this skewedness in favor of RS and CS. Whereas, it is pertinent to mention that the societal acknowledgement of ecological resources meaningfully enhanced by the tangible contribution of PS. Besides this, the resilience of an ecological system is significantly determined by the performance of SS. Therefore more focus in UES research is required on assessing the contribution/role of SS and PS for ensuring sustainable provisions of UES in the face of mounting challenges to urban environment.

A marked emphasis in the majority of the reviewed publications (Figure 6) was observed on either 1) to measure the socio-ecological impacts of urbanization and concomitant behavioral changes on provision of UES for informed decision making 2) to assess the potentials of urban ecology for ensuring human wellbeing and urban environmental resilience or 3) to decipher the consequences of global warming and climate change on the supply of UES and socio-ecological sustainability of the urban areas. These propensities in research reflect the growing consciousness for ensuring urban ecological resilience in the face of imminent social, psychological, climatic and environmental vulnerabilities of urban areas.

The assessment or evaluations of an urban phenomenon, situation, policy or problem appeared a preferred technique of enquiry (49.14\%) in the recent research (Figure 7). This analytical approach was adopted from different perspectives such as assessing the validity of a technological innovation/method (Lakes and Kim, 2012; La Rosa and Wiesmann, 2013; Schreyer and Lakes, 2016; Tigges et al., 2017), the effectiveness of a policy or planning instrument (Kaczorowska et al., 2016; Larondelle et al., 2016), or to estimate the impacts of socio-cultural factors on urban environment in studies (Kremer et al., 2013; Buchel and Frantzeskaki, 2015; Escobedo et al., 2015; Sutton and Anderson, 2016). As compared to this, the Experimental mode of enquiry was observed in a few studies $(11.21 \%)$ for estimating the potentials of green infrastructure in the given urban context (Taylor et al., 2014; Cameron et al., 2015; Coma et al., 2017) and for assessing sthe role of building material (Capener and Sikander, 2015) in regulating the climate of urban areas. Experimentations with the help of Remote Sensing (RS) and Geographic Information System (GIS) were also made in studies (Tigges et al., 2013; Schreyer and Lakes, 2014) to evaluate their effectiveness for integrated planning of urban ecological resources. The experimentations with new options and opportunities 
are incumbent but resource dependent (financial and technological resources) however, the use of GIS and RS is gaining acceptance among the research communities (Kolanuvada et al., 2016) in the developing countries and in the less developed regions (Thapa, 2012) as well. These findings corroborate the notions that application and acknowledgement of RS and GIS as a research tool for integrated urban environmental managements will increase in the future.

The exploratory style of investigation was observed in $(22.41 \%)$ studies. The method was specifically adopted in studies to understand patterns of urban land use changes (Haase et al., 2014a; Kain et al., 2016) or to explore nature based solution for the resilience of urban environment (Pataki et al., 2011; Kuittinen et al., 2016; Santiago Fink, 2016). This technique of investigation was also observed in the reviwed publications such as (Ernstson et al., 2008; Connolly et al., 2014; Kronenberg, 2015; Dennis and James, 2016b). These studies were designed to improve the environmental governance and management of urban areas.

The $(17.24 \%)$ studies based their conclusions on conceptual discourses for postulating measures to ensure the resilience of urban ecosystems. This sort of orientation in UES research was specifically observed in the studies which were conceived to address the challenges of land use changes (Stott et al., 2015; Kain et al., 2016) and socio-cultural transformations in urban areas (Ernstson et al., 2010; Andersson et al., 2014). The researchers also contributed their scholarships through conceptual framework in the studies (Rozos et al., 2013; Wu, 2014; Mcphearson et al., 2015; Haas and Ban, 2017) to improve the precision and practicability of research regarding UES.

\section{Monetary vs. non-monetary parameters for evaluating UES}

The publications were assessed to study prevailing inclinations in UES research regarding the use of monetary and/or non-monetary parameters.

The monetary assessments of cost and benefits linked with UES are vital for informed decision making (Aevermann and Schmude, 2015). After the publication of The Economics of Ecosystems and Biodiversity (TEEB) in 2011 the use of monetary parameters in ES research are gaining more recognition. The use of monetary parameters for corroborating findings was found limited $(3.45 \%)$ and restricted to the assessment mode of investigation. These findings are in line with the assertions of Sutton and Anderson (2016) that the monetary valuations of UES are more intricate and complex as compared to non-monetary valuations of ES. The overlapping nature of the benefits from UES: contestations over classification between benefits and/or services, controversies over methodology used for data acquisition and differences over spatialtemporal scale used for study are the conceivable explanations for less reliance on monetary parameters in the research concerning UES. However, the findings in monetary terms are readily and unambiguously understood in the present age of market economy and, thus, offer an effective technique for disseminating awareness about the contributions of ecological resources. Therefore, further investigations are needed to address the methodological/operational ambiguities responsible for discouraging the use of monetary parameters in UES research.

However, the majority of studies $(66.38 \%)$, irrespective of their study design or orientation, preferred non-monetary parameters for evaluations of benefits arising from the ecological infrastructure of urban areas (Alam et al., 2016; Dennis and James, 2016b; Grafius et al., 2016; Kain et al., 2016; Kolanuvada et al., 2016; Kuittinen et al., 
2016). As compared to this a substantial proportion of (18.97\%) publications based their conclusions on the cumulative outcomes of monetary and non-monetary parameters (Elmqvist et al., 2015; Kiss et al., 2015; Langemeyer et al., 2015; Czembrowski et al., 2016). The added focus towards the cumulative assessments of UES is needed for holistic appraisal regarding the contributions of natural capital. The outcomes of such a research will ensure more support from social institutions and scientific communities for integrated ecological management of urban areas. Whereas, a number of publications (11.21\%) extended their assertions through scholastic discourses or conceptual understandings rather than relying on either monetary or non-monetary measurements such as (Wu, 2014; Frantzeskaki and Kabisch, 2016; Corburn, 2017). These orientations, in the contemporary research, are indispensable for postulating out of the box strategies for uninterrupted supply of UES in the face of accelerating urbanization, ecological degradation and looming threats from climate change.

\section{Study components and UES evaluation}

The environmental component(s), relied upon for assessments in UES studies also reflect the inclinations of contemporary research. The findings in Figure 7 indicate the proportion of studies which focused on a particular component of urban environment for assessment.

The anthropocentric orientations in UES research are stressed (Alberti et al., 2003; Graça et al., 2017) for integrated urban environmental management. In line with these demands a substantial number of studies $(n=69)$ relied on the cumulative outcomes of socio-ecological parameters for drawing inferences and estimations regarding UES from diversified contextual settings such as (Ernstson et al., 2008; Buchel and Frantzeskaki, 2015; Escobedo et al., 2015; Vollmer et al., 2015; Graça et al., 2017).

It was followed by the selection of components related to urban biodiversity ( $n=64)$. The assessments about different forms of urban green infrastructures such as street trees (Kiss et al., 2015; Mcpherson et al., 2016), urban forests (Baró et al., 2014; Fusaro et al., 2015), parks (Sutton and Anderson, 2016) and impacts of urban vegetative diversity (Wang et al., 2015; Calderón-Contreras and Quiroz-Rosas, 2017) were made for different purposes ranging from the assessments of services and disservices of urban ecological infrastructure to urban planning.

A significant number of studies $(n=57)$ in the 3rd category based their findings on atmospheric components of the urban environment. The measurements and quantifications of atmospheric temperature (Taylor et al., 2014; Di Leo et al., 2016) humidity (Capener and Sikander, 2015) and gaseous components (Manes et al., 2012) were made in these studies from various aspects while evaluating their impacts on the urban environment. The acquisition of accurate, cost effective and time efficient data related to atmospheric components at different spatial scale have become possible and easier due to advancements in the atmospheric and remote sciences (Larondelle and Lauf, 2016). In this connection a growing reliance on remotely sensed data for evaluating different components of urban climate was also observed.

The component of water was analyzed in the 4th category $(n=42)$ from diversified perspectives for efficient use and management of urban blue infrastructure. The dominant orientations in the urban water studies were found towards accurate measurement of urban water resources (Larondelle and Lauf, 2016), to illustrate the importance of the rivers for urban residents (Vollmer et al., 2015; Weber and Ringold, 2015) and to postulate measures to ensure the efficient use of available water (Mccarthy 
et al., 2011). A growing interest to evaluate the impacts and complementing ability of technological innovations on urban water supply was also observed in studies (Rozos et al., 2013; Honey-Rosés et al., 2014). The components relied upon for assessment of cultural/aesthetic services such as the availability, role and importance of parks and urban green spaces were adjudged in the 5th category $(n=42)$.

Urban climatic anomalies such as the urban heat island effect, smog, haze and resultant global warming are attributed to imbalance in the atmospheric carbon emanating from industrial, vehicular and domestic sources which are mostly located in the urban areas (Rosenfeld et al., 1998; Di Leo et al., 2016). These unwarranted climatic incidents induce researchers to strive for 'green oriented' solutions to control carbon emissions and concentration in the urban areas. In response to these challenges the focus of $(n=35)$ studies in the 6th category was observed for finding plausible solutions to control and mitigate the adverse impacts of carbon concentrations in urban areas (Kuittinen et al., 2016; Tigges et al., 2017).

The assessments were made in $(n=18)$ studies to evaluate the contribution of the urban ecological resources in providing food and fuel to urban residents and to weigh their contributions in managing the energy requirements of the urban areas in $(n=14)$ studies. The market price of dwellings was also used as a proxy variable in $(n=9)$ studies to assess the interrelationship between urban environments and worth of the property.

Besides these, a large number of other components $(n=100)$ of urban environments from diversified settings were also used as parameters to evaluate the role and significance of UES for the urban areas.

\section{Focus of research in UES}

The studies in this review were designed to achieve multiple and diverse objectives, ranging from resolution of local environmental concerns to philosophical discourses for improved performance and resilience of urban ecological capital. The objectives found in the selected publications reflect the focus of these studies.The objectives set to achieve identical targets by using different linguistic expressions were condensed into eight groups for brevity and analysis (Table 1). The findings in Figure 7 reflect the proportion of studies designed to achieve a specific target.

The sustainable planning and management of UES was observed as the most common objective of $(28.45 \%)$ publications such as (Kronenberg, 2015; Stott et al., 2015; Vollmer et al., 2015; Alam et al., 2016; Dennis and James, 2016b). A closer scrutiny of the data indicates that such orientations in the research are closely associated with the industrialized nations. The appraisal of governance and policy associations with UES in (17.24\%) studies appeared as the next important stream of investigation. The studies such as (Ernstson et al., 2010; Connolly et al., 2013; Connolly et al., 2014; Kronenberg, 2015; Frantzeskaki and Kabisch, 2016) were carried out to decipher the effects of environmental governance and policy framework on their contextual urban environment.

The assessments of context specific phenomena and practices are also stressed in the recent literature (Schreyer and Lakes, 2016) to get insights for optimal utilization and resilience of urban ecological resources. The focus of (20.69\%) publications such as (Honey-Rosés et al., 2014; Youngsteadt et al., 2015; Dennis and James, 2016a; Kain et al., 2016) were found to estimate the impacts of contextual occurrences on the provisions of UES. 
To test the viability/application of new methods, techniques and approaches in the research are needed and validated in $(13.79 \%)$ research initiatives regarding UES such as (Lundy and Wade, 2011; Lakes and Kim, 2012; Pincetl, 2012; Tigges et al., 2013). The use of GIS and RS for measuring, evaluating and planning of urban ecological resources is gaining acceptance. The researchers preferred to rely on the data retrieved through RS and GIS for detecting Urban Land use changes (Thapa, 2012; La Rosa and Wiesmann, 2013), estimating carbon storage/ sequestration (Baró et al., 2014; Tigges et al., 2017), assessing water availability (Yao et al., 2015) and for the measurements of urban vegetative cover (Banzhaf and Kollai, 2015; Schreyer and Lakes, 2015; Kolanuvada et al., 2016; Schreyer, 2016; Schreyer and Lakes, 2016). Besides this, a growing trend of computer-aided modelling for better utility and conservation of urban ecological resources was observed in this review (Grêt-Regamey et al., 2013). The scholastic efforts of (Huang et al., 2011; Inostroza, 2014; Martinico et al., 2014) for improvements in methodologies, techniques and approaches for better assessments of potentials and pressures on UES were also observed in this review.

The focus in studies were also observed on postulating measures to mitigate the consequences of creeping global warming for urban areas. The orientations of $(8.62 \%)$ publications such as (Geneletti and Zardo, 2016) were found towards conjecturing on adaptive measures for the sustainability of urban environmental health, to address the challenges associated with global warming and consequential climate change. The researchers like (Mcwilliam et al., 2014; Estoque and Murayama, 2015; Grafius et al., 2016; Kaczorowska et al., 2016) tried to decipher the imprints of Urban Land use changes $(5.17 \%)$ on sustainable provision of UES and highlighted the importance of land use planning for urban environmental resilience in their studies. The content analysis also indicated a growing emphasis in UES research on the accurate assessments of urban ecological resources in (3.45\%) studies such as (Wu, 2014; Wang et al., 2015).

Besides, these dominant orientations in UES research a growing propensity in recent studies (2.59\%) was also noticed in studies such as (Corburn, 2017) to ensure equitable distribution of UES among urban inhabitants under the influence of Environmental Justice debate.

\section{Conclusions}

This study is based on a systematic review protocol applied on a set of 116 scientific publications. It provides an overview of the evolving trends and gaps in UES research. The most obvious finding of this overview is that the concept of urban ecosystem services is gaining recognition as a component of informed decision making in urban planning and as a tool to monitor socio-ecological resilience of the urban areas. This review also establishes the fact that the research regarding UES is more focused in the technologically advanced and economically developed countries which have a really significant exposure to urban based industrial activities. The appearance of environmental externalities due to earlier industrialization, pressures from the society for healthy urban environment and availability of resources to fulfill these demands are the plausible explanations for more determined efforts to ensure resilience of UES in these countries. However, the insights of these studies are also immensely important for the regions where the research regarding UES is still in its embryonic stages.

The majority of publications based their appraisals on non-monetary parameters instead of monetary measurements. However, the evaluation of ecological contributions 
in monetary terms increases the acceptability of scientific findings and encourages policy makers/planners to adopt and utilize these findings.

A greater proportion of studies in this review either relied on assessment or an exploratory mode of investigations. These research techniques are frequently used in the social sciences and are comparatively easier, however an inherent element of subjectivity associated with them may compromise the objectivities in findings. As compared to it, a reliance on experimental mode of enquiry in UES will augment the credibility of findings. However, the conceptual style of investigation is imperative for postulating novice approaches for integrated management of UES in the face of emerging challenges for the urban areas.

The outcomes of this study stress on further investigations for devising standard protocols for the monetary measurements of UES. These initiatives should, hopefully, help to overcome the operational and methodological ambiguities for assessments of UES. The future research collaborations between and among nations based upon interdisciplinary research paradigm seems a viable option to achieve this objective. The trans-national research collaborations between the developed world and the less developed regions are also incumbent for postulating comprehensive strategies. These collaborations will also provide the opportunities to retrieve data from the contextual settings of these less investigated regions for conceptual discourses at the global level. Furthermore, these initiatives will directly and indirectly extend the much needed exposure and technical support to researchers investigating UES in these regions.

It is the considered opinion of the authors of this research contribution that the Sustained focus in research on UES is more needed in the less developed regions of the world. In these geographical regions the poor are the worst victims of urban ecological degradation. Thus, sustainable and equitable provisions of UES in these regions is a question of equity and justice debate and a real challenge for the researchers and urban planners to address.

\section{REFERENCES}

[1] Aevermann, T., Schmude, J. (2015): Quantification and monetary valuation of urban ecosystem services in Munich, Germany. - Zeitschrift für Wirtschaftsgeographie 59: 188200.

[2] Alam, M., Dupras, J., Messier, C. (2016): A framework towards a composite indicator for urban ecosystem services. - Ecological Indicators 60: 38-44.

[3] Alavipanah, S., Haase, D., Lakes, T., Qureshi, S. (2017): Integrating the third dimension into the concept of urban ecosystem services: A review. - Ecological Indicators 72: 374398.

[4] Alberti, M., Marzluff, J. M., Shulenberger, E., Bradley, G., Ryan, C., Zumbrunnen, C. (2003): Integrating humans into ecology: opportunities and challenges for studying urban ecosystems. - AIBS Bulletin 53: 1169-1179.

[5] Andersson, E., Barthel, S., Borgström, S., Colding, J., Elmqvist, T., Folke, C., Gren, Å. (2014): Reconnecting cities to the biosphere: stewardship of green infrastructure and urban ecosystem services. - Ambio 43: 445-453.

[6] Banzhaf, E., Kollai, H. (2015): Monitoring the Urban Tree Cover for Urban Ecosystem Services-The Case of Leipzig, Germany. - The International Archives of Photogrammetry, Remote Sensing and Spatial Information Sciences 40: 301. 
[7] Baró, F., Chaparro, L., Gómez-Baggethun, E., Langemeyer, J., Nowak, D. J., Terradas, J. (2014): Contribution of ecosystem services to air quality and climate change mitigation policies: the case of urban forests in Barcelona, Spain. - Ambio 43: 466-479.

[8] Bolund, P., Hunhammar, S. (1999): Ecosystem services in urban areas. - Ecological Economics 29: 293-301.

[9] Buchel, S., Frantzeskaki, N. (2015): Citizens' voice: A case study about perceived ecosystem services by urban park users in Rotterdam, the Netherlands. - Ecosystem Services 12: 169-177.

[10] Bürgi, M., Silbernagel, J., Wu, J., Kienast, F. (2015): Linking ecosystem services with landscape history. - Landscape Ecology 30: 11-20.

[11] Cairns Jr, J., Palmer, S. E. (1995): Restoration of urban waterways and vacant areas: the first steps toward sustainability. - Environmental health perspectives 103: 452.

[12] Calderón-Contreras, R., Quiroz-Rosas, L. E. (2017): Analysing scale, quality and diversity of green infrastructure and the provision of Urban Ecosystem Services: A case from Mexico City. - Ecosystem Services 23: 127-137.

[13] Cameron, R. W., Taylor, J., Emmett, M. (2015): A Hedera green façade-energy performance and saving under different maritime-temperate, winter weather conditions. Building and Environment 92: 111-121.

[14] Capener, C. M., Sikander, E. (2015): Green Building Envelopes-Moisture Safety in Ventilated Light-weight Building Envelopes. - Energy Procedia 78: 3458-3464.

[15] Chaudhary, S., Mcgregor, A., Houston, D., Chettri, N. (2015): The evolution of ecosystem services: a time series and discourse-centered analysis. - Environmental Science \& Policy 54: 25-34.

[16] Ciriacy-Wantrup, S. V. (1947): Capital returns from soil-conservation practices. - Journal of farm economics 29: 1181-1196.

[17] Cohen, B. (2004): Urban growth in developing countries: a review of current trends and a caution regarding existing forecasts. - World development 32: 23-51.

[18] Coma, J., Pérez, G., De Gracia, A., Burés, S., Urrestarazu, M., Cabeza, L. F. (2017): Vertical greenery systems for energy savings in buildings: A comparative study between green walls and green facades. - Building and Environment 111: 228-237.

[19] Connolly, J. J., Svendsen, E. S., Fisher, D. R., Campbell, L. K. (2013): Organizing urban ecosystem services through environmental stewardship governance in New York City. Landscape and urban planning 109: 76-84.

[20] Connolly, J. J., Svendsen, E. S., Fisher, D. R., Campbell, L. K. (2014): Networked governance and the management of ecosystem services: The case of urban environmental stewardship in New York City. - Ecosystem Services 10: 187-194.

[21] Corburn, J. (2017): Urban place and health equity: critical issues and practices. International journal of environmental research and public health 14: 117.

[22] Costanza, R., D'arge, R., De Groot, R., Farber, S., Grasso, M., Hannon, B., Limburg, K., Naeem, S., O'neill, R. V., Paruelo, J. (1997): The value of the world's ecosystem services and natural capital. - Nature 387: 253-260.

[23] Costanza, R., Daly, H. E. (1987): Toward an ecological economics. - Ecological Modelling 38: 1-7.

[24] Czembrowski, P., Kronenberg, J., Czepkiewicz, M. (2016): Integrating non-monetary and monetary valuation methods-SoftGIS and hedonic pricing. - Ecological Economics 130: 166-175.

[25] Daily, G., Alexander, S., Ehrlich, P., Goulder, L., Lubchenco, J., Matson, P., Mooney, H., Postel, S., Schneider, S., Tilman, D. (1997): Ecosystem services: Benefits supplied to human societies by natural ecosystems, Vol. 2: Ecological Society of America Washington DC.

[26] Daily, G. C., Polasky, S., Goldstein, J., Kareiva, P. M., Mooney, H. A., Pejchar, L., Ricketts, T. H., Salzman, J., Shallenberger, R. (2009): Ecosystem services in decision making: time to deliver. - Frontiers in Ecology and the Environment 7: 21-28. 
[27] De Groot, R. S., Alkemade, R., Braat, L., Hein, L., Willemen, L. (2010): Challenges in integrating the concept of ecosystem services and values in landscape planning, management and decision making. - Ecological Complexity 7: 260-272.

[28] De Groot, R. S., Wilson, M. A., Boumans, R. M. (2002): A typology for the classification, description and valuation of ecosystem functions, goods and services. Ecological Economics 41: 393-408.

[29] Dennis, M., James, P. (2016a): Site-specific factors in the production of local urban ecosystem services: A case study of community-managed green space. - Ecosystem Services 17: 208-216.

[30] Dennis, M., James, P. (2016b): User participation in urban green commons: Exploring the links between access, voluntarism, biodiversity and well being. - Urban Forestry \& Urban Greening 15: 22-31.

[31] Di Leo, N., Escobedo, F. J., Dubbeling, M. (2016): The role of urban green infrastructure in mitigating land surface temperature in Bobo-Dioulasso, Burkina Faso. - Environment, development and sustainability 18: 373-392.

[32] Elmqvist, T., Setälä, H., Handel, S., Van Der Ploeg, S., Aronson, J., Blignaut, J. N., Gomez-Baggethun, E., Nowak, D., Kronenberg, J., De Groot, R. (2015): Benefits of restoring ecosystem services in urban areas. - Current Opinion in Environmental Sustainability 14: 101-108.

[33] Ernstson, H., Barthel, S., Andersson, E., Borgström, S. (2010): Scale-crossing brokers and network governance of urban ecosystem services: the case of Stockholm. - Ecology and society 15(4): 28. [online].

[34] Ernstson, H., Sörlin, S., Elmqvist, T. (2008): Social movements and ecosystem servicesthe role of social network structure in protecting and managing urban green areas in Stockholm. - Ecology and society 13(2):39. [online].

[35] Escobedo, F. J., Clerici, N., Staudhammer, C. L., Corzo, G. T. (2015): Socio-ecological dynamics and inequality in Bogotá, Colombia's public urban forests and their ecosystem services. - Urban Forestry \& Urban Greening 14: 1040-1053.

[36] Estoque, R. C., Murayama, Y. (2015): Intensity and spatial pattern of urban land changes in the megacities of Southeast Asia. - Land Use Policy 48: 213-222.

[37] Frantzeskaki, N., Kabisch, N. (2016): Designing a knowledge co-production operating space for urban environmental governance-Lessons from Rotterdam, Netherlands and Berlin, Germany. - Environmental Science \& Policy 62: 90-98.

[38] Fusaro, L., Salvatori, E., Mereu, S., Marando, F., Scassellati, E., Abbate, G., Manes, F. (2015): Urban and peri-urban forests in the metropolitan area of Rome: Ecophysiological response of Quercus ilex L. in two green infrastructures in an ecosystem services perspective. - Urban Forestry \& Urban Greening 14: 1147-1156.

[39] Geneletti, D., Zardo, L. (2016): Ecosystem-based adaptation in cities: An analysis of European urban climate adaptation plans. - Land Use Policy 50: 38-47.

[40] Gómez-Baggethun, E., Mingorria, S., Reyes-García, V., Calvet, L., Montes, C. (2010): Traditional ecological knowledge trends in the transition to a market economy: empirical study in the Doñana natural areas. - Conservation Biology 24: 721-729.

[41] Graça, M. S., Gonçalves, J. F., Alves, P. J., Nowak, D. J., Hoehn, R., Ellis, A., FarinhaMarques, P., Cunha, M. (2017): Assessing mismatches in ecosystem services proficiency across the urban fabric of Porto (Portugal): The influence of structural and socioeconomic variables. - Ecosystem Services 23: 82-93.

[42] Grafius, D. R., Corstanje, R., Warren, P. H., Evans, K. L., Hancock, S., Harris, J. A. (2016): The impact of land use/land cover scale on modelling urban ecosystem services. Landscape Ecology 31: 1509-1522.

[43] Grêt-Regamey, A., Celio, E., Klein, T. M., Hayek, U. W. (2013): Understanding ecosystem services trade-offs with interactive procedural modeling for sustainable urban planning. - Landscape and urban planning 109: 107-116. 
[44] Haas, J., Ban, Y. (2017): Mapping and monitoring urban ecosystem services using multitemporal high-resolution satellite data. - IEEE Journal of Selected Topics in Applied Earth Observations and Remote Sensing 10: 669-680.

[45] Haase, D., Haase, A., Rink, D. (2014a): Conceptualizing the nexus between urban shrinkage and ecosystem services. - Landscape and urban planning 132: 159-169.

[46] Haase, D., Larondelle, N., Andersson, E., Artmann, M., Borgström, S., Breuste, J., Gomez-Baggethun, E., Gren, Å., Hamstead, Z., Hansen, R. (2014b): A quantitative review of urban ecosystem service assessments: concepts, models, and implementation. Ambio 43: 413-433.

[47] Heilig, G. K. (2012): World urbanization prospects: the 2011 revision. - United Nations, Department of Economic and Social Affairs (DESA), Population Division, Population Estimates and Projections Section, New York.

[48] Honey-Rosés, J., Schneider, D. W., Brozović, N. (2014): Changing ecosystem service values following technological change. - Environmental management 53: 1146-1157.

[49] Huang, S. L., Chen, Y. H., Kuo, F. Y., Wang, S. H. (2011): Emergy-based evaluation of peri-urban ecosystem services. - Ecological Complexity 8: 38-50.

[50] Inostroza, L. (2014): Measuring urban ecosystem functions through 'Technomass'-A novel indicator to assess urban metabolism. - Ecological Indicators 42: 10-19.

[51] Kaczorowska, A., Kain, J. H., Kronenberg, J., Haase, D. (2016): Ecosystem services in urban land use planning: integration challenges in complex urban settings-case of Stockholm. - Ecosystem Services 22: 204-212.

[52] Kain, J. H., Larondelle, N., Haase, D., Kaczorowska, A. (2016): Exploring local consequences of two land-use alternatives for the supply of urban ecosystem services in Stockholm year 2050. - Ecological Indicators 70: 615-629.

[53] Kiss, M., Takács, Á., Pogácsás, R., Gulyás, Á. (2015): The role of ecosystem services in climate and air quality in urban areas: Evaluating carbon sequestration and air pollution removal by street and park trees in Szeged (Hungary). - Moravian geographical reports 23: 36-46.

[54] Kolanuvada, S. R., Mariappan, M., Krishnan, V. (2016): Demand-based urban forest planning using high-resolution remote sensing and AHP. SPIE Asia-Pacific Remote Sensing, 2016. International Society for Optics and Photonics, 98790P-98790P-98712.

[55] Kremer, P., Hamstead, Z. A., Mcphearson, T. (2013): A social-ecological assessment of vacant lots in New York City. - Landscape and urban planning 120: 218-233.

[56] Kronenberg, J. (2015): Why not to green a city? Institutional barriers to preserving urban ecosystem services. - Ecosystem Services 12: 218-227.

[57] Kronenberg, J., Hubacek, K. (2013): Could Payments for Ecosystem Services Create an" Ecosystem Service Curse"? - Ecology and society 18.

[58] Kuittinen, M., Moinel, C., Adalgeirsdottir, K. (2016): Carbon sequestration through urban ecosystem services: A case study from Finland. - Science of the Total Environment 563: 623-632.

[59] La Rosa, D., Wiesmann, D. (2013): Land cover and impervious surface extraction using parametric and non-parametric algorithms from the open-source software R: An application to sustainable urban planning in Sicily. - GIScience \& remote sensing 50: 231-250.

[60] Lakes, T., Kim, H. O. (2012): The urban environmental indicator "Biotope Area Ratio"An enhanced approach to assess and manage the urban ecosystem services using high resolution remote-sensing. - Ecological Indicators 13: 93-103.

[61] Langemeyer, J., Baró, F., Roebeling, P., Gómez-Baggethun, E. (2015): Contrasting values of cultural ecosystem services in urban areas: The case of park Montjuic in Barcelona. - Ecosystem Services 12: 178-186.

[62] Larondelle, N., Frantzeskaki, N., Haase, D. (2016): Mapping transition potential with stakeholder-and policy-driven scenarios in Rotterdam City. - Ecological Indicators 70: 630-643. 
[63] Larondelle, N., Lauf, S. (2016): Balancing demand and supply of multiple urban ecosystem services on different spatial scales. - Ecosystem Services 22: 18-31.

[64] Liu, S., Costanza, R., Farber, S., Troy, A. (2010): Valuing ecosystem services. - Annals of the New York Academy of Sciences 1185: 54-78.

[65] Lundy, L., Wade, R. (2011): Integrating sciences to sustain urban ecosystem services. Progress in Physical Geography 35: 653-669.

[66] Manes, F., Incerti, G., Salvatori, E., Vitale, M., Ricotta, C., Costanza, R. (2012): Urban ecosystem services: tree diversity and stability of tropospheric ozone removal. Ecological applications 22: 349-360.

[67] Martinico, F., La Rosa, D., Privitera, R. (2014): Green oriented urban development for urban ecosystem services provision in a medium sized city in southern Italy. - iForestBiogeosciences and Forestry 7: 385.

[68] Mccarthy, H. R., Pataki, D. E., Jenerette, G. D. (2011): Plant water-use efficiency as a metric of urban ecosystem services. - Ecological applications 21: 3115-3127.

[69] Mcphearson, T., Andersson, E., Elmqvist, T., Frantzeskaki, N. (2015): Resilience of and through urban ecosystem services. - Ecosystem Services 12: 152-156.

[70] Mcpherson, E. G., Van Doorn, N., De Goede, J. (2016): Structure, function and value of street trees in California, USA. - Urban Forestry \& Urban Greening 17: 104-115.

[71] Mcshane, T. O., Hirsch, P. D., Trung, T. C., Songorwa, A. N., Kinzig, A., Monteferri, B., Mutekanga, D., Van Thang, H., Dammert, J. L., Pulgar-Vidal, M. (2011): Hard choices: making trade-offs between biodiversity conservation and human well-being. - Biological conservation 144: 966-972.

[72] Mcwilliam, W., Brown, R., Eagles, P., Seasons, M. (2014): Barriers to the effective planning and management of residential encroachment within urban forest edges: A Southern Ontario, Canada case study. - Urban Forestry \& Urban Greening 13: 48-62.

[73] Millennium Ecosystem Assessment (2005a): Ecosystems and human well-being: synthesis. - Island, Washington, DC.

[74] Millennium Ecosystem Assessment (2005b): Millennium ecosystem assessment. Ecosystems and human wellbeing: a framework for assessment Washington, DC: Island Press.

[75] Mitchell, R. C., Carson, R. T. (2013): Using surveys to value public goods: the contingent valuation method, Routledge.

[76] Pataki, D. E., Carreiro, M. M., Cherrier, J., Grulke, N. E., Jennings, V., Pincetl, S., Pouyat, R. V., Whitlow, T. H., Zipperer, W. C. (2011): Coupling biogeochemical cycles in urban environments: ecosystem services, green solutions, and misconceptions. Frontiers in Ecology and the Environment 9: 27-36.

[77] Pincetl, S. (2012): Nature, urban development and sustainability-What new elements are needed for a more comprehensive understanding? - Cities 29: S32-S37.

[78] Rosenfeld, A. H., Akbari, H., Romm, J. J., Pomerantz, M. (1998): Cool communities: strategies for heat island mitigation and smog reduction. - Energy and Buildings 28: 5162.

[79] Rozos, E., Makropoulos, C., Maksimović, Č. (2013): Rethinking urban areas: an example of an integrated blue-green approach. - Water Science and Technology: Water Supply 13: 1534-1542.

[80] Salzman, J. (2011): What is the Emperor Wearing? The Secret Lives of Ecosystem Services. - The Secret Lives of Ecosystem Services (April 15, 2011). Pace Environmental Law (PELR) Review. 28.

[81] Santiago Fink, H. (2016): Human-nature for climate action: Nature-based solutions for urban sustainability. - Sustainability 8: 254.

[82] Schreyer, J., Lakes, T. (2014): Remote sensing-based approaches for modeling 3D vegetation information in urban areas. - Computational Science and Its Applications (ICCSA), 14th International Conference on, 2014, IEEE, 116-120. 
[83] Schreyer, J., Lakes, T. (2015): TanDEM-X \& UAV data for modeling 3D vegetation information in urban areas. - Urban Remote Sensing Event (JURSE), 2015 Joint, IEEE, $1-4$.

[84] Schreyer, J., Lakes, T. (2016): Deriving and Evaluating City-Wide Vegetation Heights from a TanDEM-X DEM. - Remote Sensing 8: 940.

[85] Spash, C. L. (2011): Social ecological economics: Understanding the past to see the future. - American Journal of Economics and Sociology 70: 340-375.

[86] Stott, I., Soga, M., Inger, R., Gaston, K. J. (2015): Land sparing is crucial for urban ecosystem services. - Frontiers in Ecology and the Environment 13: 387-393.

[87] Sutton, P. C., Anderson, S. J. (2016): Holistic valuation of urban ecosystem services in New York City's Central Park. - Ecosystem Services 19: 87-91.

[88] Taylor, J., Cameron, R., Emmett, M. (2014): The role of shrubs and climbers on improving thermal performance of brick walls during winter. - XXIX International Horticultural Congress on Horticulture: Sustaining Lives, Livelihoods and Landscapes (IHC2014): V 1108, 2014, 353-359.

[89] Teeb, T. (2011): Manual for Cities: Ecosystem Services in Urban Management. - The Economics of Ecosystems and Biodiversity (TEEB).

[90] Thapa, R. B. (2012): Monitoring landscape change in Kathmandu metropolitan region using multi-temporal satellite imagery. - SPIE Asia-Pacific Remote Sensing: 8528185281.

[91] Tigges, J., Churkina, G., Lakes, T. (2017): Modeling above-ground carbon storage: a remote sensing approach to derive individual tree species information in urban settings. Urban Ecosystems 20: 97-111.

[92] Tigges, J., Lakes, T., Hostert, P. (2013): Urban vegetation classification: Benefits of multitemporal RapidEye satellite data. - Remote Sensing of Environment 136: 66-75.

[93] United-Nations, D. O. E. a. S. A. (2014): World Urbanization Prospects: The 2014 Revision, Highlights. Department of Economic and Social Affairs. - Population Division, United Nations.

[94] Vollmer, D., Prescott, M. F., Padawangi, R., Girot, C., Grêt-Regamey, A. (2015): Understanding the value of urban riparian corridors: considerations in planning for cultural services along an Indonesian river. - Landscape and urban planning 138: 144154.

[95] Wang, H. F., Qureshi, S., Knapp, S., Friedman, C. R., Hubacek, K. (2015): A basic assessment of residential plant diversity and its ecosystem services and disservices in Beijing, China. - Applied Geography 64: 121-131.

[96] Weber, M. A., Ringold, P. L. (2015): Priority river metrics for residents of an urbanized arid watershed. - Landscape and urban planning 133: 37-52.

[97] Wu, J. (2014): Urban ecology and sustainability: The state-of-the-science and future directions. - Landscape and urban planning 125: 209-221.

[98] Yao, F., Wang, C., Dong, D., Luo, J., Shen, Z., Yang, K. (2015): High-resolution mapping of urban surface water using ZY-3 multi-spectral imagery. - Remote Sensing 7: 12336-12355.

[99] Youngsteadt, E., Henderson, R. C., Savage, A. M., Ernst, A. F., Dunn, R. R., Frank, S. D. (2015): Habitat and species identity, not diversity, predict the extent of refuse consumption by urban arthropods. - Global change biology 21: 1103-1115. 


\section{APPENDIX}

Appendix 1. 116 selected and reviewed articles

\begin{tabular}{|c|c|c|c|c|c|c|c|c|}
\hline Author Name(s) & Title & Source Title & Year & Vol. & Issue & $\begin{array}{c}\text { P. } \\
\text { Start }\end{array}$ & $\begin{array}{c}\text { P. } \\
\text { End }\end{array}$ & Doi \\
\hline Juntti Meri, Lundy Lian & $\begin{array}{l}\text { A mixed methods } \\
\text { approach to urban } \\
\text { ecosystem services: } \\
\text { Experienced } \\
\text { environmental quality } \\
\text { and its role in ecosystem } \\
\text { assessment within an } \\
\text { inner-city estate } \\
\end{array}$ & $\begin{array}{l}\text { Landscape and Urban } \\
\text { Planning }\end{array}$ & 2017 & 161 & & 10 & 21 & 10.1016/j.landurbplan.2017.01.002 \\
\hline Dan Friess & $\begin{array}{l}\text { Singapore as a long- } \\
\text { term case study for } \\
\text { tropical urban } \\
\text { ecosystem services } \\
\end{array}$ & Urban Ecosystems & 2017 & 20 & & 277 & 291 & $10.1007 / \mathrm{s} 11252-016-0592-7$ \\
\hline Chunglim Mak, Miklas Scholz, Philip James & $\begin{array}{l}\text { Sustainable drainage } \\
\text { system site assessment } \\
\text { method using urban } \\
\text { ecosystem services } \\
\end{array}$ & Urban Ecosystems & 2017 & 20 & & 293 & 307 & $10.1007 / \mathrm{s} 11252-016-0593-6$ \\
\hline Jason Corburn & $\begin{array}{l}\text { Urban Place and Health } \\
\text { Equity: Critical Issues } \\
\text { and Practices }\end{array}$ & $\begin{array}{l}\text { International Journal of } \\
\text { Environmental Research } \\
\text { and Public Health }\end{array}$ & 2017 & 14 & & & & 10.3390/ijerph14020117 \\
\hline Jan Haas, Yifang Ban & $\begin{array}{c}\text { Mapping and } \\
\text { Monitoring Urban } \\
\text { Ecosystem Services } \\
\text { Using Multitemporal } \\
\text { High-Resolution } \\
\text { Satellite Data }\end{array}$ & $\begin{array}{l}\text { IEEE Journal of } \\
\text { Selected Topics in } \\
\text { Applied Earth } \\
\text { Observations and } \\
\text { Remote Sensing }\end{array}$ & 2016 & 10 & & 669 & 680 & 10.1109/JSTARS.2016.2586582 \\
\hline Jan Tigges, Galina Churkina, Tobia Lakes & $\begin{array}{l}\text { Modeling above-ground } \\
\text { carbon storage: a remote } \\
\text { sensing approach to } \\
\text { derive individual tree }\end{array}$ & Urban Ecosystems & 2017 & 20 & & 97 & 111 & $10.1007 / \mathrm{s} 11252-016-0585-6$ \\
\hline
\end{tabular}

APPLIED ECOLOGY AND ENVIRONMENTAL RESEARCH 16(3):3545-3581.

http://www.aloki.hu • ISSN 15891623 (Print) • ISSN 17850037 (Online)

DOI: http://dx.doi.org/10.15666/aeer/1603_35453581

( ) 2018, ALÖKI Kft., Budapest, Hungary 


\begin{tabular}{|c|c|c|c|c|c|c|c|c|}
\hline & $\begin{array}{l}\text { species information in } \\
\text { urban settings }\end{array}$ & & & & & & & \\
\hline $\begin{array}{l}\text { Marisa S. Graca, Joao F. Goncalves, Paulo } \\
\text { J.M. Alves, David J. Nowak, Robert Hoehn, } \\
\text { Alexis Ellis, Paulo Farinha-Marques, Mario } \\
\text { Cunha }\end{array}$ & $\begin{array}{l}\text { Assessing mismatches } \\
\text { in ecosystem services } \\
\text { proficiency across the } \\
\text { urban fabric of Porto } \\
\text { (Portugal): The } \\
\text { influence of structural } \\
\text { and socioeconomic } \\
\text { variables }\end{array}$ & Ecosystem Services & 2017 & 23 & & 82 & 93 & 10.1016/j.ecoser.2016.11.015 \\
\hline $\begin{array}{c}\text { Rafael Calderon-Contrerasa, Laura Elisa } \\
\text { Quiroz-Rosasb }\end{array}$ & $\begin{array}{l}\text { Analysing scale, quality } \\
\text { and diversity of green } \\
\text { infrastructure and the } \\
\text { provision of Urban } \\
\text { Ecosystem Services: A } \\
\text { case from Mexico City }\end{array}$ & Ecosystem Services & 2017 & 23 & & 127 & 137 & 10.1016/j.ecoser.2016.12.004 \\
\hline $\begin{array}{c}\text { Sadroddin Alavipanaha, Dagmar Haasea, } \\
\text { Tobia Lakes,Salman Qureshi }\end{array}$ & $\begin{array}{l}\text { Integrating the third } \\
\text { dimension into the } \\
\text { concept of urban } \\
\text { ecosystem services: A } \\
\text { Review }\end{array}$ & Ecological Indicators & 2017 & 72 & & 374 & 398 & 10.1016/j.ecolind.2016.08.010 \\
\hline $\begin{array}{c}\text { Julia Coma,Gabriel Perez,Alvaro de } \\
\text { Gracia,Silvia Bures,Miguel } \\
\text { Urrestarazu,Luisa F. Cabeza }\end{array}$ & $\begin{array}{c}\text { Vertical greenery } \\
\text { systems for energy } \\
\text { savings in buildings: A } \\
\text { comparative study } \\
\text { between green walls and } \\
\text { green facades }\end{array}$ & $\begin{array}{l}\text { Building and } \\
\text { Environment }\end{array}$ & 2017 & 111 & & 228 & 237 & 10.1016/j.buildenv.2016.11.014 \\
\hline Neele Larondelle, Steffen Lauf & $\begin{array}{l}\text { Balancing demand and } \\
\text { supply of multiple urban } \\
\text { ecosystem services on } \\
\text { different spatial scales }\end{array}$ & Ecosystem Services & 2016 & 22 & & 18 & 31 & 10.1016/j.ecoser.2016.09.008 \\
\hline $\begin{array}{l}\text { Kaczorowska Annaa,Kain Jaan- } \\
\text { Henrik,Kronenberg Jakub,Haase Dagmar }\end{array}$ & $\begin{array}{l}\text { Ecosystem services in } \\
\text { urban land use planning: } \\
\text { Integration challenges in } \\
\text { complex urban settings- } \\
\text { Case of Stockholm }\end{array}$ & Ecosystem Services & 2016 & 22 & & 204 & 212 & 10.1016/j.ecoser.2015.04.006 \\
\hline Johannes Schreyer,Tobia Lakes & $\begin{array}{l}\text { Deriving and Evaluating } \\
\text { City-Wide Vegetation } \\
\text { Heights from a } \\
\text { TanDEM-X DEM }\end{array}$ & Remote Sensing & 2016 & 11 & 8 & 777 & 780 & $10.3390 / \mathrm{rs} 8110940$ \\
\hline
\end{tabular}

APPLIED ECOLOGY AND ENVIRONMENTAL RESEARCH 16(3):3545-3581.

http://www.aloki.hu • ISSN 15891623 (Print) • ISSN 17850037 (Online)

DOI: http://dx.doi.org/10.15666/aeer/1603_35453581

(c) 2018, ALÖKI Kft., Budapest, Hungary 


\begin{tabular}{|c|c|c|c|c|c|c|c|c|}
\hline $\begin{array}{c}\text { Jaan-Henrik Kaina,Neele } \\
\text { Larondelleb,Dagmar Haaseb, Anna } \\
\text { Kaczorowskaa }\end{array}$ & $\begin{array}{l}\text { Exploring local } \\
\text { consequences of two } \\
\text { land-use alternatives for } \\
\text { the supply of urban } \\
\text { ecosystem services in } \\
\text { Stockholm year } 2050\end{array}$ & Ecological Indicators & 2016 & 70 & & 615 & 629 & 10.1016/j.ecolind.2016.02.062 \\
\hline $\begin{array}{c}\text { Neele Larondelle,Niki Frantzeskaki,Dagmar } \\
\text { Haasea }\end{array}$ & $\begin{array}{l}\text { Mapping transition } \\
\text { potential with } \\
\text { stakeholder- and policy- } \\
\text { driven scenarios in } \\
\text { Rotterdam City } \\
\end{array}$ & Ecological Indicators & 2016 & 70 & & 630 & 643 & 10.1016/j.ecolind.2016.02.028 \\
\hline $\begin{array}{c}\text { Piotr Czembrowski,Jakub } \\
\text { Kronenberg,Michał Czepkiewicz }\end{array}$ & $\begin{array}{c}\text { Integrating non- } \\
\text { monetary and monetary } \\
\text { valuation methods - } \\
\text { SoftGIS and hedonic } \\
\text { pricing } \\
\end{array}$ & Ecological Economics & 2016 & 130 & & 166 & 175 & 10.1016/j.ecolecon.2016.07.004 \\
\hline Theodore S. Eisenman & $\begin{array}{l}\text { GREENING CITIES IN } \\
\text { AN URBANIZING } \\
\text { AGE The Human } \\
\text { Health Bases in the } \\
\text { Nineteenth and Early } \\
\text { Twenty-first Centuries }\end{array}$ & Change Over Time & 2016 & 6 & 1 & 216 & 246 & 10.1353/cot.2016.0014 \\
\hline $\begin{array}{l}\text { Vaino Nurmi,Athanasios Votsis,Adriaan } \\
\text { Perrels,Susanna Lehvävirta }\end{array}$ & $\begin{array}{l}\text { Green Roof Cost- } \\
\text { Benefit Analysis: } \\
\text { Special Emphasis on } \\
\text { Scenic Benefits }\end{array}$ & $\begin{array}{c}\text { Journal of Benefit-Cost } \\
\text { Analysis }\end{array}$ & 2016 & 7 & 3 & 488 & 522 & 10.1017/bca.2016.18 \\
\hline $\begin{array}{l}\text { Tom L. Green,Jakub Kronenberg,Erik } \\
\text { Andersson,Thomas Elmqvist,Erik Go'mez- } \\
\text { Baggethun }\end{array}$ & $\begin{array}{l}\text { Insurance Value of } \\
\text { Green Infrastructure in } \\
\text { and Around Cities }\end{array}$ & Ecosystems & 2016 & 19 & 6 & 1051 & 1063 & $10.1007 / \mathrm{s} 10021-016-9986-\mathrm{x}$ \\
\hline $\begin{array}{c}\text { Darren R. Grafius, Ron Corstanje,Philip H. } \\
\text { Warren,Karl L. Evans,Steven Hancock,Jim } \\
\text { A. Harris }\end{array}$ & $\begin{array}{l}\text { The impact of land } \\
\text { use/land cover scale on } \\
\text { modelling urban } \\
\text { ecosystem services }\end{array}$ & Landscape Ecology & 2016 & 31 & 7 & 1509 & 1522 & $10.1007 / \mathrm{s} 10980-015-0337-7$ \\
\hline $\begin{array}{c}\text { Matti Kuittinen,Caroline Moinel,Kristjana } \\
\text { Adalgeirsdottir }\end{array}$ & $\begin{array}{c}\text { Carbon sequestration } \\
\text { through urban } \\
\text { ecosystem services A } \\
\text { case study from Finland }\end{array}$ & $\begin{array}{l}\text { Science of the Total } \\
\text { Environment }\end{array}$ & 2016 & $\begin{array}{r}563- \\
564\end{array}$ & & 623 & 632 & 10.1016/j.scitotenv.2016.03.168 \\
\hline $\begin{array}{l}\text { Peleg Kremera,Zoé A. Hamsteadb,Timon } \\
\text { McPhearsona }\end{array}$ & $\begin{array}{l}\text { The value of urban } \\
\text { ecosystem services in } \\
\text { New York City: A }\end{array}$ & $\begin{array}{l}\text { Environmental Science } \\
\text { \& Policy }\end{array}$ & 2016 & 62 & & 57 & 68 & 10.1016/j.envsci.2016.04.012 \\
\hline
\end{tabular}

APPLIED ECOLOGY AND ENVIRONMENTAL RESEARCH 16(3):3545-3581.

http://www.aloki.hu • ISSN 15891623 (Print) • ISSN 17850037 (Online)

DOI: http://dx.doi.org/10.15666/aeer/1603_35453581

(c) 2018, ALÖKI Kft., Budapest, Hungary 


\begin{tabular}{|c|c|c|c|c|c|c|c|c|}
\hline & $\begin{array}{c}\text { spatially explicit } \\
\text { multicriteria analysis of } \\
\text { landscape scale } \\
\text { valuation scenarios }\end{array}$ & & & & & & & \\
\hline Niki Frantzeskakia,Nadja Kabischb & $\begin{array}{c}\text { Designing a knowledge } \\
\text { co-production operating } \\
\text { space for urban } \\
\text { environmental } \\
\text { governance-Lessons } \\
\text { from Rotterdam, } \\
\text { Netherlands and Berlin, } \\
\text { Germany } \\
\end{array}$ & $\begin{array}{c}\text { Environmental Science } \\
\text { \& Policy }\end{array}$ & 2016 & 62 & & 90 & 98 & 10.1016/j.envsci.2016.01.010 \\
\hline $\begin{array}{l}\text { Gregory McPhersona,Natalie van Doornb, } \\
\text { John de Goede }\end{array}$ & $\begin{array}{l}\text { Structure, function and } \\
\text { value of street trees in } \\
\text { California, USA }\end{array}$ & $\begin{array}{l}\text { Urban Forestry \& Urban } \\
\text { Greening }\end{array}$ & 2016 & 17 & & 104 & 115 & 10.1016/j.ufug.2016.03.013 \\
\hline Paul C.Sutton,SharolynJ.Anderson & $\begin{array}{l}\text { Holistic valuation of } \\
\text { urban ecosystem } \\
\text { services in New York } \\
\text { City's Central Park } \\
\end{array}$ & Ecosystem Services & 2016 & 19 & & 87 & 91 & 10.1016/j.ecoser.2016.04.003 \\
\hline $\begin{array}{l}\text { Nestor Di Leo,Francisco J. } \\
\text { Escobedo,Marielle Dubbeling }\end{array}$ & $\begin{array}{l}\text { The role of urban green } \\
\text { infrastructure in } \\
\text { mitigating land surface } \\
\text { temperature in Bobo- } \\
\text { Dioulasso, Burkina Faso }\end{array}$ & $\begin{array}{l}\text { Environment } \\
\text { Development and } \\
\text { Sustainability }\end{array}$ & 2015 & 392 & 2 & 373 & 392 & 10.1007/s10668-015-9653-y \\
\hline Helen Santiago Fink & $\begin{array}{c}\text { Human-Nature for } \\
\text { Climate Action: Nature- } \\
\text { Based Solutions for } \\
\text { Urban Sustainability }\end{array}$ & Sustainability & 2016 & 8 & 3 & 254 & 264 & $10.3390 /$ su8030254 \\
\hline $\begin{array}{c}\text { Tommaso Sitzia,Thomas } \\
\text { Campagnaro,Robert George Weir }\end{array}$ & $\begin{array}{l}\text { Novel woodland patches } \\
\text { in a small historical } \\
\text { Mediterranean city: } \\
\text { Padova, Northern Italy }\end{array}$ & Urban Ecosystems & 2015 & 19 & 1 & 475 & 487 & $10.1007 / \mathrm{s} 11252-015-0475-3$ \\
\hline M. Dennis, P.James & $\begin{array}{l}\text { Site-specific factors in } \\
\text { the production of local } \\
\text { urban ecosystem } \\
\text { services: A case study of } \\
\text { community-managed } \\
\text { green space }\end{array}$ & Ecosystem Services & 2016 & 17 & & 208 & 216 & 10.1016/j.ecoser.2016.01.003 \\
\hline Sanna-Riikka Saarela, Janne Rinne & $\begin{array}{l}\text { Knowledge brokering } \\
\text { and boundary work for }\end{array}$ & Ecological Indicators & 2016 & 61 & 1 & 49 & 62 & 10.1016/j.ecolind.2015.07.016 \\
\hline
\end{tabular}

APPLIED ECOLOGY AND ENVIRONMENTAL RESEARCH 16(3):3545-3581.

http://www.aloki.hu • ISSN 15891623 (Print) • ISSN 17850037 (Online)

DOI: http://dx.doi.org/10.15666/aeer/1603_35453581

(c) 2018, ALÖKI Kft., Budapest, Hungary 


\begin{tabular}{|c|c|c|c|c|c|c|c|}
\hline & $\begin{array}{l}\text { ecosystem service } \\
\text { indicators. An urban } \\
\text { case study in Finland }\end{array}$ & & & & & & \\
\hline $\begin{array}{c}\text { Srinivasa Raju Kolanuvada,Muneeswaran } \\
\text { Mariappan,Vani Krishnan }\end{array}$ & $\begin{array}{c}\text { Demand-Based Urban } \\
\text { Forest Planning using } \\
\text { High Resolution Remote } \\
\text { Sensing and AHP }\end{array}$ & $\begin{array}{l}\text { Lidar Remote Sensing } \\
\text { for Environmental } \\
\text { Monitoring XV }\end{array}$ & 2016 & 9879 & & & $10.1117 / 12.2223832$ \\
\hline J.E. Taylor, R.W.F. Cameron, M.R. Emmett & $\begin{array}{l}\text { The role of shrubs and } \\
\text { climbers on improving } \\
\text { thermal performance of } \\
\text { brick walls during } \\
\text { winter }\end{array}$ & $\begin{array}{c}\text { International Conference } \\
\text { on Landscape and Urban } \\
\text { Horticulture and } \\
\text { International } \\
\text { Symposium on } \\
\text { Sustainable } \\
\text { Management in the } \\
\text { Urban Forest }\end{array}$ & 2016 & 1108 & 353 & 359 & 10.17660/ActaHortic.2016.1108.47 \\
\hline M. Dennis,P. James & $\begin{array}{l}\text { User participation in } \\
\text { urban green commons: } \\
\text { Exploring the links } \\
\text { between access, } \\
\text { voluntarism, } \\
\text { biodiversity and well } \\
\text { being } \\
\end{array}$ & $\begin{array}{l}\text { Urban Forestry \& Urban } \\
\text { Greening }\end{array}$ & 2016 & 15 & 22 & 31 & 10.1016/j.ufug.2015.11.009 \\
\hline $\begin{array}{c}\text { Peleg Kremer,Zoé Hamstead,Dagmar } \\
\text { Haase,Timon McPhearson,Niki } \\
\text { Frantzeskaki,Erik Andersson,Nadja } \\
\text { Kabisch,Neele Larondelle,Emily L. } \\
\text { Rall,Annette Voigt,,Francesc Baró,Christine } \\
\text { Bertram,Erik Gómez-Baggethun ,Rieke } \\
\text { Hansen,Anna Kaczorowska,Jaan-Henrik } \\
\text { Kain,Jakub Kronenberg,Johannes } \\
\text { Langemeyer,Stephan Pauleit,Katrin } \\
\text { Rehdanz,Maria Schewenius,Chantal van } \\
\text { Ham,Daniel Wurster,Thomas Elmqvist } \\
\end{array}$ & $\begin{array}{l}\text { Key insights for the } \\
\text { future of urban } \\
\text { ecosystem services } \\
\text { research }\end{array}$ & Ecology and Society & 2016 & 21 & & & 10.5751/ES-08445-210229 \\
\hline Davide Geneletti,Linda Zardoa & $\begin{array}{c}\text { Ecosystem-based } \\
\text { adaptation in cities: An } \\
\text { analysis of European } \\
\text { urban climate adaptation } \\
\text { plans } \\
\end{array}$ & Land Use Policy & 2016 & 50 & 38 & 47 & 10.1016/j.landusepol.2015.09.003 \\
\hline $\begin{array}{c}\text { Mahbubul Alama,Jérôme Duprasb,Christian } \\
\text { Messierba }\end{array}$ & $\begin{array}{l}\text { A framework towards a } \\
\text { composite indicator for }\end{array}$ & Ecological Indicators & 2016 & 60 & 38 & 44 & 10.1016/j.ecolind.2015.05.035 \\
\hline
\end{tabular}

APPLIED ECOLOGY AND ENVIRONMENTAL RESEARCH 16(3):3545-3581.

http://www.aloki.hu • ISSN 15891623 (Print) • ISSN 17850037 (Online)

DOI: http://dx.doi.org/10.15666/aeer/1603_35453581

(c) 2018, ALÖKI Kft., Budapest, Hungary 


\begin{tabular}{|c|c|c|c|c|c|c|c|c|}
\hline & $\begin{array}{l}\text { urban ecosystem } \\
\text { services }\end{array}$ & & & & & & & \\
\hline $\begin{array}{c}\text { Alison R.Holt,Meghann Mears,Lorraine } \\
\text { Maltby,Philip Warren }\end{array}$ & $\begin{array}{l}\text { Understanding spatial } \\
\text { patterns in the } \\
\text { production of multiple } \\
\text { urban ecosystem } \\
\text { services } \\
\end{array}$ & Ecosystem Services & 2015 & 16 & & 33 & 46 & 10.1016/j.ecoser.2015.08.007 \\
\hline Ronald C. Estoque,Yuji Murayama & $\begin{array}{l}\text { Intensity and spatial } \\
\text { pattern of urban land } \\
\text { changes in the } \\
\text { megacities of Southeast } \\
\text { Asia } \\
\end{array}$ & Land Use Policy & 2015 & 48 & & 213 & 222 & 10.1016/j.landusepol.2015.05.017 \\
\hline $\begin{array}{c}\text { Hua-Feng Wang,Salman Qureshi,Sonja } \\
\text { Knapp,Cynthia Ross Friedman,Klaus } \\
\text { Hubacek }\end{array}$ & $\begin{array}{l}\text { A basic assessment of } \\
\text { residential plant } \\
\text { diversity and its } \\
\text { ecosystem services and } \\
\text { disservices in Beijing, } \\
\text { China }\end{array}$ & Applied Geography & 2015 & 64 & & 121 & 131 & 10.1016/j.apgeog.2015.08.006 \\
\hline $\begin{array}{c}\text { Ross W.F. Cameron ,Jane Taylor,Martin } \\
\text { Emmett }\end{array}$ & $\begin{array}{l}\text { A Hedera green facade - } \\
\text { Energy performance and } \\
\text { saving under different } \\
\text { maritime-temperate, } \\
\text { winter weather } \\
\text { conditions } \\
\end{array}$ & $\begin{array}{l}\text { Building and } \\
\text { Environment }\end{array}$ & 2015 & 92 & & 111 & 121 & 10.1016/j.buildenv.2015.04.011 \\
\hline $\begin{array}{c}\text { Fangfang Yao,Chao Wang,Di } \\
\text { Dong,Jiancheng Luo,Zhanfeng Shen,Kehan } \\
\text { Yang }\end{array}$ & $\begin{array}{l}\text { High-Resolution } \\
\text { Mapping of Urban } \\
\text { Surface Water Using } \\
\text { ZY-3 Multi-Spectral } \\
\text { Imagery } \\
\end{array}$ & Remote Sensing & 2015 & 7 & 9 & 12336 & 12355 & $10.3390 /$ rs 70912336 \\
\hline $\begin{array}{l}\text { Iain Stott,Masashi Soga,Richard Inger,Kevin } \\
\text { J Gaston1 }\end{array}$ & $\begin{array}{c}\text { Land sparing is crucial } \\
\text { for urban ecosystem } \\
\text { services }\end{array}$ & $\begin{array}{l}\text { Frontiers in Ecology and } \\
\text { the Environment }\end{array}$ & 2015 & 13 & 7 & 387 & 393 & $10.1890 / 140286$ \\
\hline $\begin{array}{l}\text { Christopher Luederitz,Ebba Brink,Fabienne } \\
\text { Gralla,Verena Hermelingmeier,Moritz } \\
\text { Meyer,Lisa Niven,LarsPanzer,Stefan } \\
\text { Partelowb,Anna-LenaRau,Ryuei } \\
\text { Sasaki,DavidJ.Abson,DanielJ.Lang,Christine } \\
\text { Wamsler,Henrik von Wehrden }\end{array}$ & $\begin{array}{l}\text { A review of urban } \\
\text { ecosystem services: six } \\
\text { key challenges for } \\
\text { future research }\end{array}$ & Ecosystem Services & 2015 & 14 & & 98 & 112 & 10.1016/j.ecoser.2015.05.001 \\
\hline $\begin{array}{l}\text { Marthe L. Derkzen,Astrid J. A. van } \\
\text { Teeffelen,Peter H. Verburg }\end{array}$ & $\begin{array}{l}\text { REVIEW Quantifying } \\
\text { urban ecosystem }\end{array}$ & Applied Ecology & 2015 & 52 & 4 & 1020 & 1032 & $10.1111 / 1365-2664.12469$ \\
\hline
\end{tabular}

APPLIED ECOLOGY AND ENVIRONMENTAL RESEARCH 16(3):3545-3581.

http://www.aloki.hu • ISSN 15891623 (Print) • ISSN 17850037 (Online)

DOI: http://dx.doi.org/10.15666/aeer/1603_35453581

(c) 2018, ALÖKI Kft., Budapest, Hungary 


\begin{tabular}{|c|c|c|c|c|c|c|c|c|}
\hline & $\begin{array}{l}\text { services based on high- } \\
\text { resolution data of urban } \\
\text { green space: an } \\
\text { assessment for } \\
\text { Rotterdam, the } \\
\text { Netherlands }\end{array}$ & & & & & & & \\
\hline $\begin{array}{c}\text { T Elmqvist,H Setala,SN Handel,S van der } \\
\text { Ploeg,J Aronson,JN Blignaut,E Gomez- } \\
\text { Baggethun,DJ Nowak,J Kronenberg,R de } \\
\text { Groot }\end{array}$ & $\begin{array}{l}\text { Benefits of restoring } \\
\text { ecosystem services in } \\
\text { urban areas }\end{array}$ & $\begin{array}{l}\text { Environmental } \\
\text { Sustainabilty }\end{array}$ & 2015 & 14 & & 101 & 108 & 10.1016/j.cosust.2015.05.001 \\
\hline $\begin{array}{l}\text { D. Rodriguez-Rodriguez,J.H. Kain,D. } \\
\text { Haase,F. Baro, A. Kaczorowska }\end{array}$ & $\begin{array}{l}\text { Urban self-sufficiency } \\
\text { through optimised } \\
\text { ecosystem service } \\
\text { demand. Autopian } \\
\text { perspective from } \\
\text { European cities } \\
\end{array}$ & Futures & 2015 & 70 & & 13 & 23 & 10.1016/j.futures.2015.03.007 \\
\hline $\begin{array}{c}\text { Derek Vollmera,Michaela F.Prescotta,Rita } \\
\text { Padawangib, Christophe Girota,Adrienne } \\
\text { Grêt-Regameyd }\end{array}$ & $\begin{array}{l}\text { Understanding the value } \\
\text { of urban riparian } \\
\text { corridors: } \\
\text { Considerations in } \\
\text { planning for cultural } \\
\text { services along an } \\
\text { Indonesian river }\end{array}$ & $\begin{array}{l}\text { Landscape and Urban } \\
\text { Planning }\end{array}$ & 2015 & 138 & & 144 & 154 & 10.1016/j.landurbplan.2015.02.011 \\
\hline $\begin{array}{l}\text { Kathleen L. Wolf, } \\
\text { Alicia S.T. Robbins }\end{array}$ & $\begin{array}{l}\text { Metro Nature, } \\
\text { Environmental Health, } \\
\text { and Economic Value }\end{array}$ & $\begin{array}{l}\text { Environmental Health } \\
\text { Perspect }\end{array}$ & 2015 & 123 & 5 & 390 & 398 & 10.1289/ehp. 1408216 \\
\hline $\begin{array}{l}\text { Peleg Kremer, Erik Andersson, Timon } \\
\text { McPhearson, Thomas Elmqvist }\end{array}$ & $\begin{array}{l}\text { Advancing the frontier } \\
\text { of urban ecosystem } \\
\text { services research }\end{array}$ & Ecosystem Services & 2015 & 12 & & 149 & 151 & 10.1016/j.ecoser.2015.01.008 \\
\hline $\begin{array}{c}\text { Timon McPhearson,Erik Andersson,Thomas } \\
\text { Elmqvist,Niki Frantzeskaki }\end{array}$ & $\begin{array}{l}\text { Resilience of and } \\
\text { through urban } \\
\text { ecosystem services }\end{array}$ & Ecosystem Services & 2014 & 12 & & 152 & 156 & 10.1016/j.ecoser.2014.07.012 \\
\hline Sophie Buchel,Niki Frantzeskaki & $\begin{array}{l}\text { Citizens' voice: A case } \\
\text { study about perceived } \\
\text { ecosystem services by } \\
\text { urban park users in } \\
\text { Rotterdam, the } \\
\text { Netherlands }\end{array}$ & Ecosystem Services & 2014 & 12 & & 169 & 177 & 10.1016/j.ecoser.2014.11.014 \\
\hline $\begin{array}{l}\text { Johannes Langemeyer,Francesc Baró,Peter } \\
\text { Roebeling,Erik Gómez-Baggethun }\end{array}$ & $\begin{array}{l}\text { Contrasting values of } \\
\text { cultural ecosystem }\end{array}$ & Ecosystem Services & 2014 & 12 & & 178 & 186 & 10.1016/j.ecoser.2014.11.016 \\
\hline
\end{tabular}

APPLIED ECOLOGY AND ENVIRONMENTAL RESEARCH 16(3):3545-3581.

http://www.aloki.hu • ISSN 15891623 (Print) • ISSN 17850037 (Online)

DOI: http://dx.doi.org/10.15666/aeer/1603_35453581

(c) 2018, ALÖKI Kft., Budapest, Hungary 


\begin{tabular}{|c|c|c|c|c|c|c|c|c|}
\hline & $\begin{array}{l}\text { services in urban areas: } \\
\text { The case of park } \\
\text { Montjuic in Barcelona }\end{array}$ & & & & & & & \\
\hline Christine Bertram, Katrin Rehdanz & $\begin{array}{l}\text { Preferences for cultural } \\
\text { urban ecosystem } \\
\text { services: Comparing } \\
\text { attitudes, perception, } \\
\text { and use } \\
\end{array}$ & Ecosystem Services & 2014 & 12 & & 187 & 199 & 10.1016/j.ecoser.2014.12.011 \\
\hline Jakub Kronenberg & $\begin{array}{l}\text { Why not to green a city? } \\
\text { Institutional barriers to } \\
\text { preserving urban } \\
\text { ecosystem services }\end{array}$ & Ecosystem Services & 2014 & 12 & & 218 & 227 & 10.1016/j.ecoser.2014.07.002 \\
\hline $\begin{array}{c}\text { Elsa Youngsteadt,Ryanna C. } \\
\text { Henderson,Amy M. Savage,Andrew F. } \\
\text { Ernst,Robertr.Dunn,Steven D. Frank }\end{array}$ & $\begin{array}{l}\text { Habitat and species } \\
\text { identity, not diversity, } \\
\text { predict the extent of } \\
\text { refuse consumption by } \\
\text { urban arthropods }\end{array}$ & Global Change Biology & 2015 & 21 & 3 & 1103 & 1115 & $10.1111 /$ gcb. 12791 \\
\hline Banzhaf E, Kollai, H. & $\begin{array}{c}\text { MONITORING THE } \\
\text { URBAN TREE COVER } \\
\text { FOR URBAN } \\
\text { ECOSYSTEM } \\
\text { SERVICES - THE } \\
\text { CASE OF LEIPZIG, } \\
\text { GERMANY } \\
\end{array}$ & $\begin{array}{l}\text { The International } \\
\text { Archives of } \\
\text { Photogrammetry, } \\
\text { Remote Sensing and } \\
\text { Spatial Information } \\
\text { Sciences }\end{array}$ & 2015 & XL.7 & 7 & 301 & 305 & \\
\hline Johannes Schreyer, Prof. Dr. Tobia Lakes & $\begin{array}{c}\text { TanDEM-X \& UAV } \\
\text { data for modeling 3D } \\
\text { vegetation information } \\
\text { in urban areas REPEAT } \\
\text { AT } 84 \\
\end{array}$ & $\begin{array}{c}\text { Urban Remote Sensing } \\
\text { Event }\end{array}$ & 2015 & & & & & 10.1109/JURSE.2015.7120526 \\
\hline Jeannette Sieber, Manon Pons & $\begin{array}{c}\text { Assessment of Urban } \\
\text { Ecosystem Services } \\
\text { using Ecosystem } \\
\text { Services Reviews and } \\
\text { GIS-based Tools } \\
\end{array}$ & Procedia Engineering & 2015 & 115 & & 53 & 60 & 10.1016/j.proeng.2015.07.354 \\
\hline Carl-Magnus Capener,Eva Sikander & $\begin{array}{c}\text { Green building } \\
\text { envelopes - Moisture } \\
\text { safety in ventilated } \\
\text { light-weight building } \\
\text { envelopes } \\
\end{array}$ & Procedia Engineering & 2015 & 78 & & 3458 & 3464 & 10.1016/j.egypro.2015.11.179 \\
\hline Francisco J. Escobedo,Nicola & Socio-ecological & Urban Forestry \& Urban & 2015 & 14 & 4 & 1040 & 1053 & 10.1016/j.ufug.2015.09.011 \\
\hline
\end{tabular}

APPLIED ECOLOGY AND ENVIRONMENTAL RESEARCH 16(3):3545-3581.

http://www.aloki.hu • ISSN 15891623 (Print) • ISSN 17850037 (Online)

DOI: http://dx.doi.org/10.15666/aeer/1603_35453581

(c) 2018, ALÖKI Kft., Budapest, Hungary 


\begin{tabular}{|c|c|c|c|c|c|c|c|c|}
\hline $\begin{array}{l}\text { Clerici,Christina L. Staudhammer,Germán } \\
\text { Tovar Corzo }\end{array}$ & $\begin{array}{l}\text { dynamics and inequality } \\
\text { in Bogota, Colombia's } \\
\text { public urban forests and } \\
\text { their ecosystem services }\end{array}$ & Greening & & & & & & \\
\hline $\begin{array}{l}\text { Lina Fusaro,Elisabetta Salvatori,Simone } \\
\text { Mereu,Federica Marando,Elisabetta } \\
\text { Scassellati,Giovanna Abbate,Fausto Manes }\end{array}$ & $\begin{array}{l}\text { Urban and peri-urban } \\
\text { forests in the } \\
\text { metropolitan area of } \\
\text { Rome: Ecophysiological } \\
\text { response of Quercus ilex } \\
\text { L. in two green } \\
\text { infrastructures in an } \\
\text { ecosystem services } \\
\text { perspective }\end{array}$ & $\begin{array}{l}\text { Urban Forestry \& Urban } \\
\text { Greening }\end{array}$ & 2015 & 14 & 4 & 1147 & 1156 & 10.1016/j.ufug.2015.10.013 \\
\hline Tim Aevermann,Jürgen Schmude & $\begin{array}{l}\text { Quantification and } \\
\text { monetary valuation of } \\
\text { urban ecosystem } \\
\text { services in Munich, } \\
\text { Germany } \\
\end{array}$ & $\begin{array}{l}\text { The German Journal of } \\
\text { Economic Geography }\end{array}$ & 2015 & 59 & 3 & & & 10.1515/zfw-2015-0304 \\
\hline O. Adegun, S. Odunuga, O. S. Ajayi & $\begin{array}{c}\text { Climate, runoff and } \\
\text { landuse trends in the } \\
\text { Owo River Catchment } \\
\text { in Nigeria } \\
\text { HYDROLOGIC NON- } \\
\text { STATIONARITY AND } \\
\text { EXTRAPOLATING } \\
\text { MODELS TO } \\
\text { PREDICT THE } \\
\text { FUTURE }\end{array}$ & $\begin{array}{c}\text { Proceedings of the } \\
\text { International } \\
\text { Association of } \\
\text { Hydrological Sciences; } \\
\text { Gottingen }\end{array}$ & 2015 & 371 & & 137 & 142 & 10.5194/piahs-371-137-2015 \\
\hline $\begin{array}{c}\text { Kathleen L. Wolf,Marcus K. } \\
\text { Measells,Stephen C. Grado,Alicia S.T. } \\
\text { Robbins }\end{array}$ & $\begin{array}{c}\text { Economic values of } \\
\text { metro nature health } \\
\text { benefits: A life course } \\
\text { approach }\end{array}$ & $\begin{array}{l}\text { Urban Forestry \& Urban } \\
\text { Greening }\end{array}$ & 2015 & 14 & 3 & 694 & 701 & 10.1016/j.ufug.2015.06.009 \\
\hline $\begin{array}{l}\text { Morton KISS ,Agnes TAKACS,Réka } \\
\text { POGACSAS,Agnes GULYAS }\end{array}$ & $\begin{array}{l}\text { The role of ecosystem } \\
\text { services in climate and } \\
\text { air quality in urban } \\
\text { areas: Evaluating carbon } \\
\text { sequestration and air } \\
\text { pollution removal by } \\
\text { street and park trees in } \\
\text { Szeged (Hungary) }\end{array}$ & $\begin{array}{l}\text { MORAVIAN } \\
\text { GEOGRAPHICAL } \\
\text { REPORTS }\end{array}$ & 2015 & 23 & 3 & & & $10.1515 / \mathrm{mgr}-2015-0016$ \\
\hline
\end{tabular}

APPLIED ECOLOGY AND ENVIRONMENTAL RESEARCH 16(3):3545-3581.

http://www.aloki.hu • ISSN 15891623 (Print) • ISSN 17850037 (Online)

DOI: http://dx.doi.org/10.15666/aeer/1603_35453581

(c) 2018, ALÖKI Kft., Budapest, Hungary 


\begin{tabular}{|c|c|c|c|c|c|c|c|}
\hline Nadja Kabisch & $\begin{array}{l}\text { Ecosystem service } \\
\text { implementation and } \\
\text { governance challenges } \\
\text { in urban green space } \\
\text { planning-The case of } \\
\text { Berlin, Germany }\end{array}$ & Land Use Policy & 2015 & 42 & 557 & 567 & 10.1016/j.landusepol.2014.09.005 \\
\hline Matthew A. Weber,Paul L. Ringold & $\begin{array}{l}\text { Priority river metrics for } \\
\text { residents of an } \\
\text { urbanized arid } \\
\text { watershed }\end{array}$ & $\begin{array}{l}\text { Landscape and Urban } \\
\text { Planning }\end{array}$ & 2015 & 133 & 37 & 52 & 10.1016/j.landurbplan.2014.09.006 \\
\hline $\begin{array}{c}\text { Wei Li,Jean-Daniel M. Saphores,Thomas W. } \\
\text { Gillespie }\end{array}$ & $\begin{array}{l}\text { A comparison of the } \\
\text { economic benefits of } \\
\text { urban green spaces } \\
\text { estimated with NDVI } \\
\text { and with high-resolution } \\
\text { land cover data }\end{array}$ & $\begin{array}{l}\text { Landscape and Urban } \\
\text { Planning }\end{array}$ & 2015 & 133 & 105 & 117 & 10.1016/j.landurbplan.2014.09.013 \\
\hline $\begin{array}{c}\text { James J.T. Connolly,Erika S. Svendsen,Dana } \\
\text { R. Fisher,Lindsay K. Campbell }\end{array}$ & $\begin{array}{l}\text { Networked governance } \\
\text { and the management of } \\
\text { ecosystem services: The } \\
\text { case of urban } \\
\text { environmental } \\
\text { stewardship in New } \\
\text { York City } \\
\end{array}$ & Ecosystem Services & 2015 & 10 & 187 & 194 & 10.1016/j.ecoser.2014.08.005 \\
\hline Dagmar Haase,Annegret Haase,Dieter Rink & $\begin{array}{l}\text { Conceptualizing the } \\
\text { nexus between urban } \\
\text { shrinkage and } \\
\text { ecosystem services }\end{array}$ & $\begin{array}{l}\text { Landscape and Urban } \\
\text { Planning }\end{array}$ & 2015 & 132 & 159 & 169 & 10.1016/j.landurbplan.2014.09.003 \\
\hline $\begin{array}{l}\text { Yafei Wang,Frank Bakker,Rudolf de } \\
\text { Groot,Heinrich Wörtche }\end{array}$ & $\begin{array}{l}\text { Effect of ecosystem } \\
\text { services provided by } \\
\text { urban green } \\
\text { infrastructure on indoor } \\
\text { environment: A } \\
\text { literature review } \\
\end{array}$ & $\begin{array}{l}\text { Building and } \\
\text { Environment }\end{array}$ & 2014 & 77 & 88 & 100 & 10.1016/j.buildenv.2014.03.021 \\
\hline Luis Inostroza & $\begin{array}{c}\text { Measuring urban } \\
\text { ecosystem functions } \\
\text { through Technomass'-A } \\
\text { novel indicator to assess } \\
\text { urban metabolism } \\
\end{array}$ & Ecological Indicators & 2014 & 42 & 10 & 19 & 10.1016/j.ecolind.2014.02.035 \\
\hline $\begin{array}{l}\text { Iris Lehmann,Juliane Mathey,Stefanie } \\
\text { Rößler,Anne Bräuer,Valeri Goldberg }\end{array}$ & $\begin{array}{l}\text { Urban vegetation } \\
\text { structure types as a }\end{array}$ & Ecological Indicators & 2014 & 42 & 58 & 72 & 10.1016/j.ecolind.2014.02.036 \\
\hline
\end{tabular}

APPLIED ECOLOGY AND ENVIRONMENTAL RESEARCH 16(3):3545-3581.

http://www.aloki.hu • ISSN 15891623 (Print) • ISSN 17850037 (Online)

DOI: http://dx.doi.org/10.15666/aeer/1603_35453581

(c) 2018, ALÖKI Kft., Budapest, Hungary 


\begin{tabular}{|c|c|c|c|c|c|c|c|c|}
\hline & $\begin{array}{l}\text { methodological } \\
\text { approach for identifying } \\
\text { ecosystem services - } \\
\text { Application to the } \\
\text { analysis of micro- } \\
\text { climatic effects }\end{array}$ & & & & & & & \\
\hline $\begin{array}{c}\text { Jordi Honey-Rose,Nicholas Brozovic,Daniel } \\
\text { W. Schneider }\end{array}$ & $\begin{array}{c}\text { Changing Ecosystem } \\
\text { Service Values } \\
\text { Following } \\
\text { Technological Change } \\
\end{array}$ & $\begin{array}{c}\text { Environmental } \\
\text { Management }\end{array}$ & 2014 & 53 & 6 & 1146 & 1157 & $10.1007 / \mathrm{s} 00267-014-0270-6$ \\
\hline $\begin{array}{c}\text { Francesco Martinico, Daniele La Rosa, } \\
\text { Riccardo Privitera }\end{array}$ & $\begin{array}{l}\text { Green oriented urban } \\
\text { development for urban } \\
\text { ecosystem services } \\
\text { provision in a medium } \\
\text { sized city in southern } \\
\text { Italy }\end{array}$ & $\begin{array}{l}\text { Biogeosciences and } \\
\text { Forestry }\end{array}$ & 2014 & 7 & & 385 & 395 & 10.3832/ifor1171-007 \\
\hline $\begin{array}{c}\text { Neele Larondelle,Dagmar Haase,Nadja } \\
\text { Kabisch }\end{array}$ & $\begin{array}{c}\text { Mapping the diversity of } \\
\text { regulating ecosystem } \\
\text { services in European } \\
\text { cities }\end{array}$ & $\begin{array}{l}\text { Global Enviornmental } \\
\text { Change }\end{array}$ & 2014 & 26 & & 119 & 129 & 10.1016/j.gloenvcha.2014.04.008 \\
\hline Jianguo $\mathrm{Wu}$ & $\begin{array}{l}\text { Urban ecology and } \\
\text { sustainability: The state- } \\
\text { of-the-science and } \\
\text { future directions }\end{array}$ & $\begin{array}{l}\text { Landscape and Urban } \\
\text { Planning }\end{array}$ & 2014 & 125 & & 209 & 221 & 10.1016/j.landurbplan.2014.01.018 \\
\hline Jack Ahern,Sarel Cilliers,Jari Niemelä & $\begin{array}{l}\text { The concept of } \\
\text { ecosystem services in } \\
\text { adaptive urban planning } \\
\text { and design: A } \\
\text { framework for } \\
\text { supporting innovation }\end{array}$ & $\begin{array}{l}\text { Landscape and Urban } \\
\text { Planning }\end{array}$ & 2014 & 125 & & 254 & 259 & 10.1016/j.landurbplan.2014.01.020 \\
\hline $\begin{array}{c}\text { Dagmar Haase, Niki Frantzeskaki, Thomas } \\
\text { Elmqvist }\end{array}$ & $\begin{array}{l}\text { Ecosystem Services in } \\
\text { Urban Landscapes: } \\
\text { Practical Applications } \\
\text { and Governance } \\
\text { Implications } \\
\end{array}$ & AMBIO & 2014 & 43 & 4 & 407 & 412 & $10.1007 / \mathrm{s} 13280-014-0503-1$ \\
\hline $\begin{array}{c}\text { Dagmar Haase,Neele Larondelle,Erik } \\
\text { Andersson,Martina Artmann,Sara } \\
\text { Borgstrom,Jurgen Breuste,Erik Gomez- } \\
\text { Baggethun,Asa Gren, Zoe Hamstead,Rieke } \\
\text { Hansen,Nadja Kabisch,Peleg }\end{array}$ & $\begin{array}{l}\text { A Quantitative Review } \\
\text { of Urban Ecosystem } \\
\text { Service Assessments: } \\
\text { Concepts, Models, and } \\
\text { Implementation }\end{array}$ & AMBIO & 2014 & 43 & 4 & 413 & 433 & $10.1007 / \mathrm{s} 13280-014-0504-0$ \\
\hline
\end{tabular}

APPLIED ECOLOGY AND ENVIRONMENTAL RESEARCH 16(3):3545-3581.

http://www.aloki.hu • ISSN 15891623 (Print) • ISSN 17850037 (Online)

DOI: http://dx.doi.org/10.15666/aeer/1603_35453581

(c) 2018, ALÖKI Kft., Budapest, Hungary 


\begin{tabular}{|c|c|c|c|c|c|c|c|c|}
\hline $\begin{array}{c}\text { Kremer,Johannes Langemeyer,Emily } \\
\text { Lorance Rall,Timon McPhearson,Stephan } \\
\text { Pauleit,Salman Qureshi,Nina } \\
\text { Schwarz,Annette Voigt,Daniel } \\
\text { Wurster,Thomas Elmqvist } \\
\end{array}$ & & & & & & & & \\
\hline $\begin{array}{l}\text { Erik Andersson,Stephan Barthel,Sara } \\
\text { Borgstrom,Johan Colding,Thomas } \\
\text { Elmqvist,Carl Folke,Asa Gren }\end{array}$ & $\begin{array}{l}\text { Reconnecting Cities to } \\
\text { the Biosphere: } \\
\text { Stewardship of Green } \\
\text { Infrastructure and Urban } \\
\text { Ecosystem Services } \\
\end{array}$ & AMBIO & 2014 & 43 & 4 & 445 & 453 & $10.1007 / \mathrm{s} 13280-014-0506-\mathrm{y}$ \\
\hline Daniel Wurster, Martina Artmann & $\begin{array}{l}\text { Development of a } \\
\text { Concept for Non- } \\
\text { monetary Assessment of } \\
\text { Urban Ecosystem } \\
\text { Services at the Site } \\
\text { Level } \\
\end{array}$ & AMBIO & 2014 & 43 & 4 & 454 & 465 & $10.1007 / \mathrm{s} 13280-014-0502-2$ \\
\hline $\begin{array}{c}\text { Francesc Baro,Lydia Chaparro,Erik Gomez- } \\
\text { Baggethun, Johannes Langemeyer,David J. } \\
\text { Nowak,Jaume Terradas }\end{array}$ & $\begin{array}{c}\text { Contribution of } \\
\text { Ecosystem Services to } \\
\text { Air Quality and Climate } \\
\text { Change Mitigation } \\
\text { Policies: The Case of } \\
\text { Urban Forests in } \\
\text { Barcelona, Spain }\end{array}$ & AMBIO & 2014 & 43 & 4 & 466 & 479 & $10.1007 / \mathrm{s} 13280-014-0507-\mathrm{x}$ \\
\hline Marek Giergiczny, Jakub Kronenberg & $\begin{array}{l}\text { From Valuation to } \\
\text { Governance: Using } \\
\text { Choice Experiment to } \\
\text { Value Street Trees } \\
\end{array}$ & AMBIO & 2014 & 43 & 4 & 492 & 501 & $10.1007 / \mathrm{s} 13280-014-0516-9$ \\
\hline $\begin{array}{c}\text { Timon McPhearson, Zoe A. Hamstead, } \\
\text { Peleg Kremer }\end{array}$ & $\begin{array}{l}\text { Urban Ecosystem } \\
\text { Services for Resilience } \\
\text { Planning and } \\
\text { Management in New } \\
\text { York City } \\
\end{array}$ & AMBIO & 2014 & 43 & 4 & 502 & 515 & $10.1007 / \mathrm{s} 13280-014-0509-8$ \\
\hline Martina Artmann & $\begin{array}{c}\text { Assessment of Soil } \\
\text { Sealing Management } \\
\text { Responses, Strategies, } \\
\text { and Targets Toward } \\
\text { Ecologically Sustainable } \\
\text { Urban Land Use } \\
\text { Management }\end{array}$ & AMBIO & 2014 & 43 & 4 & 530 & 541 & $10.1007 / \mathrm{s} 13280-014-0511-1$ \\
\hline Anna Kaczorowska & Ecosystem Services and & ISOCARP International & 2014 & & & 1080 & 1090 & \\
\hline
\end{tabular}

APPLIED ECOLOGY AND ENVIRONMENTAL RESEARCH 16(3):3545-3581.

http://www.aloki.hu • ISSN 15891623 (Print) • ISSN 17850037 (Online)

DOI: http://dx.doi.org/10.15666/aeer/1603_35453581

(c) 2018, ALÖKI Kft., Budapest, Hungary 


\begin{tabular}{|c|c|c|c|c|c|c|c|c|}
\hline & $\begin{array}{l}\text { Urban Resilience - Case } \\
\text { of Stockholm }\end{array}$ & $\begin{array}{c}\text { Planning Congress: } \\
\text { URBAN } \\
\text { TRANSFORMATIONS: } \\
\text { CITIES AND WATER }\end{array}$ & & & & & & \\
\hline Johannes Schreyer, Tobia Lakes & $\begin{array}{c}\text { Remote sensing-based } \\
\text { approaches for modeling } \\
\text { 3D vegetation } \\
\text { information in urban } \\
\text { areas }\end{array}$ & $\begin{array}{c}\text { International Conference } \\
\text { on Computational } \\
\text { Science and Its } \\
\text { Applications }\end{array}$ & 2014 & 14 & & & & 10.1109/ICCSA.2014.30 \\
\hline $\begin{array}{c}\text { Wendy McWilliam,Robert Brown,Paul } \\
\text { Eagles,Mark Seasons }\end{array}$ & $\begin{array}{l}\text { Barriers to the effective } \\
\text { planning and } \\
\text { management of } \\
\text { residential } \\
\text { encroachment within } \\
\text { urban forest edges: A } \\
\text { Southern Ontario, } \\
\text { Canada case study }\end{array}$ & $\begin{array}{c}\text { Urban Forestry \& Urban } \\
\text { Greening }\end{array}$ & 2014 & 13 & 1 & 48 & 62 & 10.1016/j.ufug.2013.08.002 \\
\hline Jürgen Breuste,Salman Qureshi,Junxiang Li & $\begin{array}{c}\text { Applied urban ecology } \\
\text { for sustainable urban } \\
\text { environment }\end{array}$ & Urban Ecosystem & 2013 & 16 & & 675 & 680 & $10.1007 / \mathrm{s} 11252-013-0337-9$ \\
\hline Robert F. Young & $\begin{array}{l}\text { Mainstreaming urban } \\
\text { ecosystem services: A } \\
\text { national survey of } \\
\text { municipal foresters }\end{array}$ & Urban Ecosystem & 2013 & 16 & 4 & 703 & 722 & $10.1007 / \mathrm{s} 11252-013-0287-2$ \\
\hline $\begin{array}{c}\text { Peleg Kremer,Zoé A.Hamstead,Timon } \\
\text { McPhearson }\end{array}$ & $\begin{array}{c}\text { A social-ecological } \\
\text { assessment of vacant } \\
\text { lots in New York City }\end{array}$ & $\begin{array}{l}\text { Landscape and Urban } \\
\text { Planning }\end{array}$ & 2013 & 120 & & 218 & 233 & 10.1016/j.landurbplan.2013.05.003 \\
\hline $\begin{array}{l}\text { Izaskun Casado-Arzuaga,Iosu } \\
\text { Madariaga,Miren Onaindia }\end{array}$ & $\begin{array}{l}\text { Perception, demand and } \\
\text { user contribution to } \\
\text { ecosystem services in } \\
\text { the Bilbao Metropolitan } \\
\text { Greenbelt }\end{array}$ & $\begin{array}{c}\text { Journal of } \\
\text { Environmental } \\
\text { Management }\end{array}$ & 2013 & 129 & & 33 & 43 & 10.1016/j.jenvman.2013.05.059 \\
\hline Sarah Taylor Lovell,John R. Taylor & $\begin{array}{c}\text { Supplying urban } \\
\text { ecosystem services } \\
\text { through multifunctional } \\
\text { green infrastructure in } \\
\text { the United States }\end{array}$ & Landscape Ecology & 2013 & 28 & 8 & 1447 & 1463 & 10.1007/s10980-013-9912-y \\
\hline Jan Tigges, Tobia Lakes,Patrick Hostert & $\begin{array}{c}\text { Urban vegetation } \\
\text { classification: Benefits } \\
\text { of multitemporal Rapid }\end{array}$ & $\begin{array}{l}\text { Remote Sensing of } \\
\text { Environment }\end{array}$ & 2013 & 136 & & 66 & 75 & 10.1016/j.rse.2013.05.001 \\
\hline
\end{tabular}

APPLIED ECOLOGY AND ENVIRONMENTAL RESEARCH 16(3):3545-3581.

http://www.aloki.hu • ISSN 15891623 (Print) • ISSN 17850037 (Online)

DOI: http://dx.doi.org/10.15666/aeer/1603_35453581

(c) 2018, ALÖKI Kft., Budapest, Hungary 


\begin{tabular}{|c|c|c|c|c|c|c|c|c|}
\hline & Eye satellite data & & & & & & & \\
\hline Neele Larondelle,Dagmar Haase & $\begin{array}{c}\text { Urban ecosystem } \\
\text { services assessment } \\
\text { along a rural-urban } \\
\text { gradient: A cross- } \\
\text { analysis of European } \\
\text { cities }\end{array}$ & Ecological Indicators & 2012 & 29 & & 179 & 190 & 10.1016/j.ecolind.2012.12.022 \\
\hline Daniele La Rosa,Daniel Wiesmann & $\begin{array}{l}\text { Land cover and } \\
\text { impervious surface } \\
\text { extraction using } \\
\text { parametric and non- } \\
\text { parametric algorithms } \\
\text { from the open-source } \\
\text { software R: an } \\
\text { application to } \\
\text { sustainable urban } \\
\text { planning in Sicily }\end{array}$ & $\begin{array}{l}\text { GIS Science and Remote } \\
\text { Sensing }\end{array}$ & 2013 & 50 & 2 & 231 & 250 & $10.1080 / 15481603.2013 .795307$ \\
\hline Erik Gómez-Baggethun,David N. Barton & $\begin{array}{l}\text { Classifying and valuing } \\
\text { ecosystem services for } \\
\text { urban planning }\end{array}$ & Ecological Economics & 2012 & 86 & & 235 & 345 & 10.1016/j.ecolecon.2012.08.019 \\
\hline E. Rozos,C. Makropoulos, C Maksimovic & $\begin{array}{l}\text { Rethinking urban areas: } \\
\text { an example of an } \\
\text { integrated blue-green }\end{array}$ & $\begin{array}{l}\text { Water Science and } \\
\text { Technology }\end{array}$ & 2013 & 13 & 6 & 1534 & 1542 & $10.2166 /$ ws. 2013.140 \\
\hline $\begin{array}{l}\text { Simon Farrugia,Malcolm D. } \\
\text { Hudson,Lindsay McCulloch }\end{array}$ & $\begin{array}{l}\text { An evaluation of flood } \\
\text { control and urban } \\
\text { cooling ecosystem } \\
\text { services delivered by } \\
\text { urban green } \\
\text { infrastructure }\end{array}$ & $\begin{array}{c}\text { International Journal of } \\
\text { Biodiversity Science, } \\
\text { Ecosystem } \\
\text { Services \& Management }\end{array}$ & 2013 & 9 & & 136 & 145 & $10.1080 / 21513732.2013 .782342$ \\
\hline Robert F. Young,E. Gregory McPherson & $\begin{array}{l}\text { Governing metropolitan } \\
\text { green infrastructure in } \\
\text { the United States }\end{array}$ & $\begin{array}{l}\text { Landscape and Urban } \\
\text { Planning }\end{array}$ & 2012 & 109 & 1 & 67 & 75 & 10.1016/j.landurbplan.2012.09.004 \\
\hline $\begin{array}{l}\text { James J. Connolly,Erika S. Svendsen,Dana } \\
\text { R. Fisher,Lindsay K. Campbell }\end{array}$ & $\begin{array}{c}\text { Organizing urban } \\
\text { ecosystem services } \\
\text { through environmental } \\
\text { stewardship governance } \\
\text { in New York City }\end{array}$ & $\begin{array}{l}\text { Landscape and Urban } \\
\text { Planning }\end{array}$ & 2012 & 109 & 1 & 76 & 84 & 10.1016/j.landurbplan.2012.07.001 \\
\hline $\begin{array}{c}\text { Adrienne Grêt-Regamey,Enrico } \\
\text { Celio,Thomas M. Klein,Ulrike Wissen } \\
\text { Hayek }\end{array}$ & $\begin{array}{l}\text { Understanding } \\
\text { ecosystem services } \\
\text { trade-offs with }\end{array}$ & $\begin{array}{l}\text { Landscape and Urban } \\
\text { Planning }\end{array}$ & 2013 & 109 & 1 & 107 & 116 & 10.1016/j.landurbplan.2012.10.011 \\
\hline
\end{tabular}

APPLIED ECOLOGY AND ENVIRONMENTAL RESEARCH 16(3):3545-3581.

http://www.aloki.hu • ISSN 15891623 (Print) • ISSN 17850037 (Online)

DOI: http://dx.doi.org/10.15666/aeer/1603_35453581

(c) 2018, ALÖKI Kft., Budapest, Hungary 


\begin{tabular}{|c|c|c|c|c|c|c|c|c|}
\hline & $\begin{array}{l}\text { interactive procedural } \\
\text { modeling for sustainable } \\
\text { urban planning }\end{array}$ & & & & & & & \\
\hline Kathleen Gail Radford,Philip James & $\begin{array}{l}\text { Changes in the value of } \\
\text { ecosystem services } \\
\text { along a rural-urban } \\
\text { gradient:A case study of } \\
\text { Greater Manchester, UK }\end{array}$ & $\begin{array}{l}\text { Landscape and Urban } \\
\text { Planning }\end{array}$ & 2012 & 109 & 1 & 117 & 127 & 10.1016/j.landurbplan.2012.10.007 \\
\hline Stephanie Pincetl & $\begin{array}{c}\text { Nature, urban } \\
\text { development and } \\
\text { sustainability - What } \\
\text { new elements are } \\
\text { needed for a more } \\
\text { comprehensive } \\
\text { understanding? }\end{array}$ & Cities & 2012 & 29 & 2 & $\mathrm{~S} 32$ & S37 & 10.1016/j.cities.2012.06.009 \\
\hline Tobia Lakes,Hyun-Ok Kim & $\begin{array}{c}\text { The urban } \\
\text { environmental indicator } \\
\text { "Biotope Area Ratio"- } \\
\text { An enhanced approach } \\
\text { to assess and manage } \\
\text { the urban ecosystem } \\
\text { services using high } \\
\text { resolution remote- } \\
\text { sensing }\end{array}$ & Ecological Indicators & 2011 & 13 & 1 & 93 & 103 & 10.1016/j.ecolind.2011.05.016 \\
\hline Rajesh Bahadur Thapa & $\begin{array}{c}\text { Monitoring landscape } \\
\text { change in Kathmandu } \\
\text { metropolitan region } \\
\text { using multi-temporal } \\
\text { satellite imagery } \\
\end{array}$ & $\begin{array}{c}\text { Earth Observing } \\
\text { Missions and Sensors: } \\
\text { Development, } \\
\text { Implementation, and } \\
\text { Characterization II } \\
\end{array}$ & 2012 & 8528 & & & & $10.1117 / 12.978927$ \\
\hline $\begin{array}{c}\text { Fausto Manes,Guido Incerti,Elisabetta } \\
\text { Salvatori,Marcello Vitale,Carlo } \\
\text { Ricotta,Robert Costanza }\end{array}$ & $\begin{array}{l}\text { Urban ecosystem } \\
\text { services: tree diversity } \\
\text { and stability of } \\
\text { tropospheric ozone } \\
\text { removal }\end{array}$ & Ecological Applications & 2011 & 22 & 1 & 349 & 360 & $10.1890 / 11-0561.1$ \\
\hline $\begin{array}{l}\text { Heather R. Mccarthy,Diane E. Pataki,G. } \\
\text { Darrel Jenerette }\end{array}$ & $\begin{array}{c}\text { Plant water-use } \\
\text { efficiency as a metric of } \\
\text { urban ecosystem } \\
\text { services }\end{array}$ & Ecological Applications & 2011 & 21 & 8 & 3115 & 3127 & $10.1890 / 11-0048.1$ \\
\hline L. Lundy, R. Wade & $\begin{array}{l}\text { Integrating sciences to } \\
\text { sustain urban ecosystem }\end{array}$ & $\begin{array}{c}\text { Progress in Physical } \\
\text { Geography }\end{array}$ & 2011 & 35 & 5 & 653 & 669 & $10.1177 / 0309133311422464$ \\
\hline
\end{tabular}

APPLIED ECOLOGY AND ENVIRONMENTAL RESEARCH 16(3):3545-3581.

http://www.aloki.hu • ISSN 15891623 (Print) • ISSN 17850037 (Online)

DOI: http://dx.doi.org/10.15666/aeer/1603_35453581

(c) 2018, ALÖKI Kft., Budapest, Hungary 


\begin{tabular}{|c|c|c|c|c|c|c|c|c|}
\hline & services & & & & & & & \\
\hline $\begin{array}{l}\text { Shu-Li Huang, Yu-Hwa Chen,Fei-Yu } \\
\text { Kuo,Szu-Hua Wang }\end{array}$ & $\begin{array}{c}\text { Emergy-based } \\
\text { evaluation of pen-urban } \\
\text { ecosystem services }\end{array}$ & Ecological Complexity & 2010 & 8 & 1 & 38 & 50 & 10.1016/j.ecocom.2010.12.002 \\
\hline $\begin{array}{c}\text { Diane E Pataki,Margaret M } \\
\text { Carreiro,Jennifer Cherrier,Nancy E } \\
\text { Grulke,Viniece Jennings,Stephanie } \\
\text { Pincetl,Richard V Pouyat,Thomas H } \\
\text { Whitlow,Wayne C Zipperer }\end{array}$ & $\begin{array}{c}\text { Coupling } \\
\text { biogeochemical cycles } \\
\text { in urban environments: } \\
\text { ecosystem services, } \\
\text { green solutions, and } \\
\text { misconceptions }\end{array}$ & $\begin{array}{c}\text { Frontiers in Ecology and } \\
\text { the Environment }\end{array}$ & 2011 & 9 & 1 & 27 & 36 & $10.1890 / 090220$ \\
\hline $\begin{array}{c}\text { Henrik Ernstson,Stephan Barthel,Erik } \\
\text { Andersson,Sara T. Borgström }\end{array}$ & $\begin{array}{c}\text { Scale-Crossing Brokers } \\
\text { and Network } \\
\text { Governance of Urban } \\
\text { Ecosystem Services: } \\
\text { The Case of Stockholm }\end{array}$ & Ecology and Society & 2010 & 15 & 4 & & & \\
\hline Klaus Lorenz,Rattan Lal & $\begin{array}{l}\text { Biogeochemical } \mathrm{C} \text { and } \\
\mathrm{N} \text { cycles in urban soils }\end{array}$ & $\begin{array}{l}\text { Environment } \\
\text { International }\end{array}$ & 2008 & 35 & 1 & 1 & 8 & 10.1016/j.envint.2008.05.006 \\
\hline $\begin{array}{c}\text { Henrik Ernstson,Sverker Sörlin,Thomas } \\
\text { Elmqvist }\end{array}$ & $\begin{array}{l}\text { Social Movements and } \\
\text { Ecosystem Services-the } \\
\text { Role of Social Network } \\
\text { Structure in Protecting } \\
\text { and Managing Urban } \\
\text { Green Areas in } \\
\text { Stockholm }\end{array}$ & Ecology and Society & 2008 & 13 & 2 & & & \\
\hline $\begin{array}{c}\text { Susannah E. Gill,John F. Handleya,A. } \\
\text { Roland Ennosb, Stephan Pauleit,Nicolas } \\
\text { Theuraya,Sarah J. Lindleya }\end{array}$ & $\begin{array}{l}\text { Characterising the urban } \\
\text { environment of UK } \\
\text { cities and towns: A } \\
\text { template for landscape } \\
\text { planning }\end{array}$ & $\begin{array}{l}\text { Landscape and Urban } \\
\text { Planning }\end{array}$ & 2008 & 87 & 3 & 210 & 222 & 10.1016/j.landurbplan.2008.06.008 \\
\hline
\end{tabular}


Appendix 2. The table showing the name of urban centres and number of UES studies conducted

\begin{tabular}{|c|c|c|}
\hline City & Country & Number of Studies \\
\hline Berlin & Germany & 9 \\
\hline New York & USA & 7 \\
\hline Stockholm & Sweden & 6 \\
\hline Manchester & UK & 5 \\
\hline Rotterdam & Netherland & 4 \\
\hline Catalonia & Spain & 3 \\
\hline Barcelona & Spain & 3 \\
\hline Leipzig & Germany & 3 \\
\hline London & UK & 2 \\
\hline Singapore & Singapore & 2 \\
\hline Lodz & Poland & 2 \\
\hline Reading & UK & 2 \\
\hline Bogota & Colombia & 2 \\
\hline Rome & Italy & 2 \\
\hline California & USA & 2 \\
\hline Shanghai & China & 1 \\
\hline Porto & Portugal & 1 \\
\hline Mexico City & Mexico & 1 \\
\hline Helsinki & Finland & 1 \\
\hline Milton Keynes, Bedford, Luton & UK & 1 \\
\hline Espoo & Finland & 1 \\
\hline California & USA & 1 \\
\hline Bobo-Dioulasso & Burkina Faso & 1 \\
\hline Padova & Italy & 1 \\
\hline Tampere & Finland & 1 \\
\hline Chennai & India & 1 \\
\hline Mascouche (MONTREAL) & Canada & 1 \\
\hline Sheffield & UK & 1 \\
\hline Manila, Bangkok & Philippines, Thailand & 1 \\
\hline Beijing & China & 1 \\
\hline Qingdao & China & 1 \\
\hline Jakarta & Indonesia & 1 \\
\hline Boras & Sweden & 1 \\
\hline Munich & Germany & 1 \\
\hline Lagos & Nigeria & 1 \\
\hline Szeged & Hungary & 1 \\
\hline Tucson (Arizona) & USA & 1 \\
\hline Dresden & Germany & 1 \\
\hline Salzburg & Austria & 1 \\
\hline Ontario & Canada & 1 \\
\hline Bilbao & Spain & 1 \\
\hline Southampton & UK & 1 \\
\hline Masdar City & Abu Dhabi & 1 \\
\hline Seoul, Berlin & South Korea, Germany & 1 \\
\hline Kathmandu & Nepal & 1 \\
\hline Taipei & China & 1 \\
\hline
\end{tabular}


Appendix 3. The content analysis showing the number and proportion of reviewed publications focused a specific type of UES and also indicating the contemporary trends in research regarding techniques for enquiry, methods for evaluation, research/study objectives and environmental components relied upon for assessments

\begin{tabular}{|c|c|c|}
\hline $\begin{array}{l}\text { The assessment criteria and research orientations of selected } \\
\text { Publications }\end{array}$ & No. of studies & $(\%)$ \\
\hline \multicolumn{3}{|l|}{ Type of Ecosystem services/ Disservices } \\
\hline Ecosystem Services & 71 & 31.84 \\
\hline Cultural Services & 37 & 16.59 \\
\hline Regulatory Services & 65 & 29.15 \\
\hline Provisioning Services & 28 & 12.56 \\
\hline Supporting Service & 9 & 4.04 \\
\hline Disservice & 13 & 5.83 \\
\hline \multicolumn{3}{|l|}{ Technique of enquiry } \\
\hline Assessment & 57 & 49.14 \\
\hline Exploratory & 26 & 22.41 \\
\hline Experimental & 13 & 11.21 \\
\hline Conceptual framework & 20 & 17.24 \\
\hline \multicolumn{3}{|l|}{ Method of Evaluation } \\
\hline Monetary & 4 & 3.45 \\
\hline Non-Monetary & 77 & 66.38 \\
\hline Both (M - NM) & 22 & 18.97 \\
\hline Not Applicable & 13 & 11.21 \\
\hline \multicolumn{3}{|l|}{ Research/study Objective } \\
\hline Landuse Planning & 6 & 5.17 \\
\hline Planning and Management & 33 & 28.45 \\
\hline Assessment of Method & 16 & 13.79 \\
\hline Urban Ecology & 4 & 3.45 \\
\hline Environmental Justice & 3 & 2.59 \\
\hline Assessment study & 24 & 20.69 \\
\hline Governance and Policy & 20 & 17.24 \\
\hline Climate Adaption & 10 & 8.62 \\
\hline \multicolumn{3}{|l|}{ Environmental Component(s) evaluated } \\
\hline Water Management & 42 & 9.33 \\
\hline Climate Regulation & 57 & 12.67 \\
\hline Socioecological & 69 & 15.33 \\
\hline Biodiversity & 64 & 14.22 \\
\hline Aesthetics & 42 & 9.33 \\
\hline Food Fuel & 18 & 4.00 \\
\hline Energy & 14 & 3.11 \\
\hline Human Health & 24 & 5.33 \\
\hline Carbon Segestration Storage & 35 & 7.78 \\
\hline Hedonic Pricing & 9 & 2.00 \\
\hline Others & 76 & 16.89 \\
\hline
\end{tabular}

